\title{
In Good Company
}

\section{The Influence of Peers on Industry Engagement by Academic Scientists}

Tartari, Valentina; Perkmann, Markus; Salter, Ammon

Document Version

Final published version

Published in:

Research Policy

DOI:

10.1016/j.respol.2014.02.003

Publication date:

2014

\section{License}

CC BY

Citation for published version (APA):

Tartari, V., Perkmann, M., \& Salter, A. (2014). In Good Company: The Influence of Peers on Industry Engagement by Academic Scientists. Research Policy, 23(7), 1189-1203.

https://doi.org/10.1016/j.respol.2014.02.003

Link to publication in CBS Research Portal

\section{General rights}

Copyright and moral rights for the publications made accessible in the public portal are retained by the authors and/or other copyright owners and it is a condition of accessing publications that users recognise and abide by the legal requirements associated with these rights.

Take down policy

If you believe that this document breaches copyright please contact us (research.lib@cbs.dk) providing details, and we will remove access to the work immediately and investigate your claim. 


\title{
In good company: The influence of peers on industry engagement by academic scientists
}

\author{
Valentina Tartari ${ }^{\mathrm{a}, *}$, Markus Perkmann $^{\mathrm{b}}{ }$ Ammon Salter $^{\mathrm{c}}$ \\ a Department of Innovation and Organizational Economics, Copenhagen Business School, Denmark \\ b Imperial College London, Business School, United Kingdom \\ c School of Management, University of Bath, United Kingdom
}

\section{A R T I C L E I N F O}

\section{Article history:}

Received 11 December 2012

Received in revised form

17 September 2013

Accepted 9 February 2014

Available online 3 April 2014

\section{Keywords:}

University-industry relations

Academic engagement

Commercialization

Scientists

Peer effects

\begin{abstract}
A B S T R A C T
Previous research on academic entrepreneurship and engagement with industry has found that the behaviour of academics is influenced by their local social context. However, we know little about the mechanisms that produce this effect. We argue that academic scientists' industry engagement is influenced significantly by the behaviour of their peers, that is, the behaviour of colleagues of similar seniority. Using insights from social psychology, we hypothesize that these peer effects are produced by the mechanism of social comparison. In an analysis of data from multiple sources for 1370 UK academic scientists and engineers, we find that peer effects are stronger for early career individuals and weaker for star scientists, suggesting the incidence of social comparison. We argue that individuals look to their immediate peers for inspiration, because they view them as an important reference group and use them as a benchmark for their own ambitions and behaviours. Our findings have important implications for how universities may encourage scientists' behaviours by paying attention to local work contexts.
\end{abstract}

(C) 2014 The Authors. Published by Elsevier B.V. This is an open access article under the CC BY license (http://creativecommons.org/licenses/by/3.0/).

\section{Introduction}

There is broad agreement that interactions between public science and industry contribute significantly to innovation in products, processes and services (Mansfield, 1991; Cohen et al., 2002; Murray, 2002). It is also true that there can be simultaneous benefits for academic science from interactions with industry since many academics work in more applied fields, such as medicine and engineering (Nelson and Rosenberg, 1994), and industry problems traditionally have served as a powerful stimulus for progress in both basic and applied science (Rosenberg, 1982; Stokes, 1997). These interactions can take many forms from collaborative research to more direct commercial activities such as the founding of university spin-out firms (Louis et al., 1989; Agrawal and Henderson, 2002; D’Este and Patel, 2007).

While academic scientists have long participated in practical problem-solving (Geuna and Muscio, 2009; Mowery, 2009), since the early 1980 s the emergence of novel technological opportunities, for example, in biotechnology or computer science, have renewed interest in the conditions that facilitate university-industry interaction (Mowery et al., 2001).

\footnotetext{
* Corresponding author. Tel.: +45 38153965

E-mail address: vt.ino@cbs.dk (V. Tartari).
}

Governments increasingly view universities as 'engines of economic growth' (Feller, 1990), and universities are keen to acquire resources via commercialization and industry collaboration, prompting researchers to investigate what drives individual academic researchers to cooperate with industry. Many authors have investigated the role played by individual characteristics and organizational factors such as the attributes of universities ( $\mathrm{Di}$ Gregorio and Shane, 2003; Lockett and Wright, 2005).

A smaller, but growing body of research considers how the local social context in which academics operate influences their propensity to engage with industry and to commercialize their research (Louis et al., 1989; Stuart and Ding, 2006; Bercovitz and Feldman, 2008). This line of work suggests that individual academics and their achievements are highly influenced by the attitudes and behaviours of their work colleagues, the prevailing local norms, and the local leaders. In other words, academics often emulate their colleagues' behaviours; parallel evidence exists on entrepreneurial behaviour, indicating that an individual's immediate work colleagues exert considerable influence on the individual's propensity to found a firm (Nanda and Sorensen, 2010).

However, despite the insights from previous work, we still know little about why individual academics behave in similar ways to their local colleagues. For instance, we are yet to understand whether local effects emanate from a common culture or norms, collective learning and imitation, or hierarchical imposition of 
policies. In this paper, we argue that peer effects play a key role in shaping academics' behaviours. We explore how peer effects shape individuals' academic engagement, which encompasses the various ways that academic scientists collaborate with third-party organizations, and includes collaborative research, contract research and consulting as well as informal networking with practitioners (Perkmann et al., 2013). Academic engagement involves a large proportion of academic scientists across many disciplines, generates income for universities and may result in commercialization extending to licensing of patents and spin-out activities (Perkmann et al., 2013). Given the relevance of academics' engagement with industry for innovation and problem-solving (Cohen et al., 2002), it is important to develop a detailed understanding of what drives scientists' collaboration.

We argue that the influence of the local environment on academic scientists is in the form of peer effects, manifested by emulation of the behaviours of colleagues of the same rank. Using insights from social psychology, we argue also that these peer effects are largely underpinned by the tendency for individual academics' to compare themselves with other individuals. Social comparison involves individuals choosing a reference group to use as a yardstick to measure their own ambitions and behaviours (Hyman, 1942; Ibarra and Andrews, 1993). The incidence of social comparison suggests the presence of some degree of intradepartmental rivalry, as individuals compare themselves with similarly ranked colleagues in order to advance their careers in competitive professional environments.

We develop hypotheses to investigate the idea that peer effects are generated by social comparison dynamics, and test them using data from multiple sources on 1371 UK academic scientists in a range of universities and disciplines. We pay particular attention to the so-called 'reflection problem' which often affects econometric studies of peer effects and can result in spurious correlations (Manski, 1993). The reflection problem refers to the overstating of the incidence of peer effects in studies proposing that individual behaviour is explained by the average behaviour of a group (Manski, 1993). We perform several tests to rule out possible alternative explanations for real endogenous peer effects.

Our study highlights the extent to which academic engagement is shaped by the behaviour of the focal individuals' peers. We try to both identify the nature of this local social influence and partly exclude a variety of other mechanisms that might be responsible for generating behavioural alignment in local work contexts. We suggest that individuals look to their immediate peers for inspiration, predominantly because they view these individuals as an important reference group; they 'benchmark' their own ambitions and behaviours against those of their similarly ranked peers. At the same time, we note the absence of effects exerted by local social norms in informing individuals' engagement behaviours, as implied by some previous research (Louis et al., 1989; Haeussler and Colyvas, 2011). Our findings have important implications for the way specific behaviours, related to engagement of academics in local work contexts, might be promoted by universities.

\section{Theoretical background}

Academia is unique in allowing individuals to engage proactively in a wide range of diverse activities from start-up entrepreneur, to government advisor and other civil society roles. Chief amongst the work areas where academics have considerable discretion is collaboration with industry partners. This type of activity requires initiative on the part of the academic to approach and develop relations with industry partners, going beyond the conventions of academia related to teaching obligations. However, in many universities, academics' engagement with industry is less valuable for career progression than publications and other research-related outputs. So what drives individuals to engage with industry?

Previous work focuses primarily on personal attributes to explain the propensity to engage with industry, that is, on individual scientific productivity, demographic attributes, social capital, experience and professional status (Louis et al., 1989; D'Este and Patel, 2007; Bekkers and Bodas Freitas, 2008; Boardman and Ponomariov, 2009; Giuliani et al., 2010; D’Este and Perkmann, 2011; Haeussler and Colyvas, 2011). This research is complemented by studies exploring the role of organizational structures and other attributes including the features of specialized technology transfer units, and university or department research quality (Bozeman and Gaughan, 2007; D'Este and Patel, 2007; Ponomariov, 2008).

Some studies of the determinants of academic scientists' participation in commercialization have found that the social context in which individuals are embedded is an important explanatory factor. Using a sample of US-based life scientists, Stuart and Ding (2006) find that the greater the involvement of university and department colleagues and co-authors in private sector firms, the more likely an individual academic will be an entrepreneur. Being embedded in an academic department with a culture that is supportive of entrepreneurial activities can help to counteract the disincentives created by a university environment that does not reward such efforts (Kenney and Goe, 2004). A qualitative study on university patenting by Owen-Smith and Powell (2001) illustrates how the prestige associated with successful commercialization affects the aspirations of individuals. Those engaging in successful commercialization can become role models, providing powerful inspiration to work colleagues (Kassicieh et al., 1996; Wright et al., 2004). Bercovitz and Feldman (2008) confirm the existence of such peer effects in their study of medical researchers; they find that individuals are more likely to disclose inventions if departmental colleagues of similar seniority had done so. Also, Giuliani et al. (2010) show in the context of wine research in Chile, South Africa and Italy that the number of industry contacts in the networks of departmental colleagues was positively associated with the scope of an individual's personal network of industry contacts.

Thus, the emphasis has shifted from individual characteristics and organizational structures to consideration of how the local social environment can stimulate proactive behaviour among academics. While one may suspect that similar considerations may hold for greater participation in the traditional missions of the university sector, very few studies have addressed this question. Louis et al. (1989) found that local norms were more powerful predictors of various types of engagement than individual characteristics and Aschhoff and Grimpe (2014), using publications data, show that the publishing behaviours of both departmental colleagues and academic co-authors' shape researchers' academic engagement with industry, with this effect being more pronounced in the earlier stages of their academic careers.

While this emerging body of work suggests that scientists' social environments play an important role in shaping their discretionary activities, it does not point to the specific mechanisms that generate this effect. In this paper, we develop a theory that emphasizes the role of peers. A peer group is a specific type of reference group, which the individual takes account of when selecting a behaviour amongst several alternatives (Hyman, 1942; Kemper, 1968). An individual's peers are defined as those individuals in the immediate social context of similar rank and similar attributes to the focal individual. The influence of peers on individual behaviour has been documented in many different empirical settings, including neighbourhoods (Dietz, 2002), education (Coleman, 1966; Jackson and Bruegmann, 2009), movie sales (Moretti, 2011), health plan choices (Sorensen, 2006), and workplace contexts (Lazega, 2000; Nanda and Sorensen, 2010). 


\section{Hypothesis development}

We consider departmental colleagues of similar rank as the salient peer group for the academic's work-related behaviour. The department is a central organizational feature of academic life and is constituted by the immediate community of work colleagues. Although departments may be composed of smaller units, 'the department' is the principal locus of decision-making in academia (Alpert, 1985). Working in a department imposes obligations and responsibilities on academic staff, such as sharing teaching workloads and participating in departmental committees. Hiring, promotion and applications for tenure are normally decided first at department level before consideration by the university. Within the same university, departments may differ about expectations related to scholarship, organizational citizenship behaviour and attitudes to commercialization.

In developing our hypotheses for how the departmental context can shape individual academics' engagement with industry, we draw on social psychology - specifically, social comparison theory (Festinger, 1954; Tafjel, 1981; Wills, 1981). Social comparison theory postulates that individuals have an intrinsic tendency to self-evaluate, and that such self-evaluation is often informed by comparison with others (Festinger, 1954). In drawing on others' abilities and achievements, self-evaluation becomes a driver of imitative behaviour. Emulating others' actions allows individuals not only to reduce perceived discrepancy between themselves and others, but also improves their conception of themselves by seeking to do better (Festinger, 1954). Since not everyone can outdo his or her peers, the state of equilibrium is elusive and competition ensues. Hence, both social influence and competitive behaviour derive from the same socio-psychological process, that is, social comparison (Festinger, 1954).

If we consider the characteristics of academia as a professional system in which individuals work and build their careers, its competitive nature is evident. Although science relies strongly on collaboration within and across laboratories (Adams et al., 2005), it is also a system in which individuals compete for status and resources. The principle of priority means that the benefits from a discovery accrue almost exclusively to the scientist who first published it (Merton, 1973). Thus, scientists compete to be the first to report a discovery, and receive status and resources on this basis (Whitley, 2000). This competitive process is played out within scientific communities, which are stratified social systems where high-status individuals gain disproportionate benefits compared to the other participants (Zuckerman, 1970; Cole and Cole, 1974). The population of universities as the employers of academics is itself highly stratified, with the most prestigious institutions continuously capturing a disproportionate share of government grants and industry contracts (Jones et al., 2008). The stratification of the science system implies that there are major professional gains from a high-status position and, hence, that scientists have a strong incentive to compete for the most senior positions (Stephan, 1996).

Competition in science is manifested in various ways. Because many scientists have suffered from someone else being the first to publish their scientific discovery, they resort to secrecy and withholding of information from others in the community (Hagstrom, 1974; Blumenthal et al., 1996). In addition, as the membership of scientific teams increases, there is intense competition over first authorship on joint scientific publications (Knorr-Cetina and Harré, 1981). Cases of scientific misconduct are illustrative of the desirability of the rewards that the science system offers to those who achieve prominence (Furman et al., 2012). Especially from the 1980s onwards, opportunities for academic entrepreneurship and academic engagement-and hence impliclity for financial gain-have become an additional area of competition for scientific colleagues (Stephan and Everhart, 1998). At the same time, fiscal budgetary constraints have forced policy makers in many countries to encourage universities to move towards more competitive sources of funding (Geuna and Nesta, 2006), which results in academics competing for funding in a resource-constrained environment.

If one agrees that competition in science at least partly arises from the need for of individuals to compare themselves with relevant others, one needs to define the reference group for this comparison. A reference group is the group of people that individuals elect as a benchmark for their ambitions and to measure their progress (Merton and Kitt, 1950; Ibarra and Andrews, 1993; Guryan et al., 2007). Individuals tend to compare themselves with others whom they consider as having similar attitudes or abilities, and ignore those who deviate markedly from themselves (Festinger, 1954). Thus, the peer group is an important reference group of closely proximate individuals of similar rank, within the wider social context. Peer group members are likely to have similar abilities and achievement records and, hence, provide a realistic yardstick for self-evaluation. The peer group acts as a standard or checkpoint that can be used to evaluate a situation and, particularly, the individual's position in it (Zimmerman, 2003; Mas and Moretti, 2009; Bercovitz and Feldman, 2008). Peer groups can be a yardstick for ambition, based on the desire to relate to and be accepted by a group (Shibutani, 1955). By implication, when deciding to engage in specific behaviours, individuals will emulate the behaviours they observe in their peer group.

If we apply these considerations to the subject of our study, this means that junior faculty members will compare themselves with departmental colleagues of similar rank rather than with senior colleagues with much higher achievement. Engagement with industry is particularly likely to involve comparison with departmental peers. On the one hand, comparison is particularly important in relation to behaviours that are discretionary and not proscribed by formal rules; when seeking engagement with industry which is not governed by formal university rules, academics will be particularly likely to look to their peers for clues about how to behave. On the other hand, in seeking industry funding for personal research projects or engaging in potentially lucrative consulting projects, the outcomes are uncertain and comparative self-evaluation with peers can be useful to build confidence. Individuals observe their colleagues and establish individual ambitions by emulating the observed behaviour. Self-categorization theory (Turner et al., 1987; Hogg and Abrams, 1988) suggests that uncertainty promotes ingroup identification and makes the members of an individual's peer reference group the focus of social comparison. The above considerations lead us to hypothesize that:

H1. The extent of an academic's engagement with industry is positively associated with the extent of their departmental peers' industry engagement.

The hypothesis above states simply that in departments with high average industry engagement, the focal individual will demonstrate equally high levels of industry engagement, while in departments with low average levels of engagement, individuals will be deterred from engaging with industry. We now consider how the degree to which an individual is susceptible to peer effects is moderated by personal characteristics. The direction of these moderation effect will provide support for our basic hypothesis that individuals' industry engagement is, to a considerable degree, driven by the mechanism of social comparison.

A characteristic likely to influence individuals' propensity to take behavioural cues from their work peers is their seniority in the university. Professional competition for senior positions in academic science is fierce, and success depends heavily on what the individual achieves in the early stages of his or her career. Even small differences in performance can result in large differences in 
professional pay-offs (Freeman et al., 2001). However, the salient reference groups against which individuals evaluate themselves in the face of the competition are likely to vary according to professional rank. It can be argued that the more junior the academic, the more likely the salient reference group will be represented by local peers. Junior scientists are more concerned about career advancement than their more senior colleagues (Baldwin and Blackburn, 1981) and usually will work against locally defined benchmarks for promotion or tenure. When evaluating their performance, therefore, comparison with local colleagues will be inevitable, particularly in departmental situations where numerous individuals are competing for a limited number of senior positions. On the other hand, more senior colleagues, apart from their already achieved level of professional security, operate within wider networks and are likely to occupy pockets within their scientific communities. In their quest for self-evaluation, they are less likely to look to their departmental peers. So, because junior scientists benchmark themselves against that group, they will be more likely emulate the activities of local peers with regard to engagement with industry while for senior members we can expect a smaller effect of such local influence.

H2. The effect of an academic's departmental peers on the extent of his/her engagement with industry decreases with the individual's degree of seniority.

Next, we investigate how individual performance affects academics' susceptibility to peer behaviour. It has been documented that a small group of highly effective researchers plays a disproportionate role within a scientific community in terms of productivity (Zucker and Darby, 1996). 'Star' scientists also outperform their colleagues in terms of engagement in the commercialization of research, and are responsible for a significant share of universities' economic activities (Zucker and Darby, 1996).

High performance is closely correlated to status within the scientific community. Over time, the status of 'stars' becomes selfreinforcing because reputation attracts larger flows of resources, and provides higher visibility, resulting in more attention to the research outputs of these individuals (Merton, 1968). It is unlikely that these overachieving scientists will choose their 'average' departmental colleagues as a reference group for self-evaluation and comparison. Social comparison often involves the selective search for clues that confirm the similarity of one's peers to oneself (Mussweiler and Strack, 2000). For star scientists, 'similar others' are more likely to be represented by other stars in the scientific community than by departmental colleagues. In contrast, 'average' researchers will prefer to compare themselves to equals within their academic departmental colleagues. Thus, lower performers will tend to follow the behaviour of departmental peers more than star performers - a further confirmation of the presence of the social comparison processes underpinning peer effects in academic departments. We hypothesize that:

H3. The effect of an academic's departmental peers on the extent of his/her engagement with industry decreases with the individual's scientific performance.

\section{Data and methodology}

\subsection{Data}

To explore our hypotheses, we exploited a unique dataset covering a population of 6200 academic researchers in the UK, compiled from various sources. These include information on this population of scientists from the records of principal investigators and coinvestigators awarded grants from the UK Engineering and Physical Sciences Research Council (EPSRC) in the period 1992-2006. The
EPSRC is the largest research funding body in the UK and in 2008 disbursed $£ 740 \mathrm{~m}$ for research across all fields of engineering, mathematics, chemistry and physics. The EPSRC encourages partnerships between researchers and third parties, such as private firms, public bodies, non-profit organizations, etc. However, for most research projects, there is no requirement to have an industrial partner. The selection of projects is based solely on peer review by a panel of academic and non-academic reviewers. We used the EPSRC data to obtain information on each academic's research funding profile, including amounts of funding received. This data is comprehensive and covers all academics granted EPSRC funding in the UK over a period of 15 years.

First, we conducted an Internet-based survey of the 6200 academics listed in the EPSRC records, who were listed as active academics on their respective university websites. The questionnaire covered various aspects of individuals' academic engagement, such as engagement type and frequency, and attitudes to engagement. The survey instrument exploited items and scales deployed in previous surveys of academics (Bozeman and Gaughan, 2007; D'Este and Patel, 2007; Link et al., 2007) and included several questions exploring individual attitudes to industry engagement and entrepreneurship. A draft version of the questionnaire was piloted with 30 academics at a research-intensive university. The final questionnaire was administered to the whole population between April and September 2009 with a cover letter signed by the Chief Executive Officer of the EPSRC, followed a few days later by an email containing a personalized link to access the survey. Nonrespondents were followed-up by two further email messages and where necessary two telephone reminders. We obtained a total of 2194 completed questionnaires, corresponding to a response rate of $36 \%$.

Second, we drew on data collected from a survey administered to the same population in 2004 (D'Este and Patel, 2007) which also asked about frequency of engagement with industry; 735 individuals responded to both waves of the survey.

Third, we matched our sample with the population of academics included in the 2008 Research Assessment Exercise (RAE) (HEFCE, 2008b). The RAE was a government-mandated programme to assess the research quality of all higher education institutions in the UK; for simplicity we refer to them below as 'universities'. The assessment was carried out via disciplinary panel reviews of each department's publication output, research environment and research ranking. The results were used to determine the allocation of research funding in subsequent years to universities. RAE submissions contain information on 'units of assessment', usually departments or similar units, including their size and the amount and nature of funding received in each of the previous seven years. We used this information to develop measures of the departmental environment for each individual in our sample.

Fourth, we matched the universities included in our sample with data derived from the government's Higher Education-Business and Community Interaction Survey (HE-BCI) conducted in 2008, covering the years 2005-2007 (HEFCE, 2008a). This annual mandatory survey records university level financial and output data on a range of knowledge exchange activities, from commercialization, delivery of professional training, consultancy, contract research and services, to community-oriented activities.

Fifth, to capture details on respondents' scientific performance, we collected bibliographic information from ISI Web of Science, including number of an individual's journal articles, number of citations, names of the journals, and associated disciplines.

Our final data source was EUROSTAT (2003), which provides information on the university region (NUTS2 level), including Gross Domestic Product (GDP), business expenditure on Research and Development (R\&D), and patent applications. This data provides information on the regional economic context in which the 
Table 1

Types of academic engagement.

\begin{tabular}{|c|c|c|}
\hline Type of interaction $(j)$ & Frequency \% $\left(b_{j}=1\right)$ & Broad engagement type \\
\hline Attendance at conferences with industry and university & 82.7 & Networking \\
\hline Attendance at industry sponsored meetings & 63.6 & Networking \\
\hline A new contract research agreement & 58.0 & Research service \\
\hline A new joint research agreement & 57.5 & Joint research \\
\hline Postgraduate training with a company & 47.7 & Training collaboration \\
\hline A new consultancy agreement & 47.6 & Research service \\
\hline Training of company employees & 30.4 & Training collaboration \\
\hline Creation of new physical facilities with industry funding & 17.3 & Joint research \\
\hline
\end{tabular}

academics operate; some local environments offer greater opportunities than others for academic engagement.

We performed several checks on the sample used for the analysis to ensure its representativeness for our population. First, to check the reliability of our survey response pool, we conducted some tests on the response population, looking for sources of bias in our sample. In particular, we analysed whether there were differences between respondents and non-respondents according to status and type of their university affiliation. We performed a Wilcoxon-Mann-Whitney test and found no significant difference. Second, because only grant holders were targeted, there was a risk of sample selection bias since non-grant holders might behave differently in terms of engagement with industry. Since we did not have information on academics that had not received a grant in the period 1992 to 2006, as a proxy for non-grant holders we used the group of academics in our survey that had not received a grant in the years 2000 to 2006. We compared their level of involvement with industry with that of academics who had received a grant in 2000-2006 and found no statistically significant differences across our key dependent and independent variables. Third, we performed checks on the characteristics of early vs late respondents and found no major differences between the two populations ${ }^{1}$.

\subsubsection{Dependent variables}

Our main dependent variable captures academics' industry engagement behaviour through the construction of an index. The academic engagement index is a modified version of an index developed by Bozeman and Gaughan (2007). We used information from our survey data on types and frequencies of academics' engagement to construct the index (see Table 1). These items cover a broader range of academic engagement forms than captured in previous studies of peer effects in academic contexts and, hence, provide a comprehensive picture of individuals' activities.

The index was constructed as follows. First, for every type of engagement we established whether the researcher had engaged or not ('occurrence', denoted by $b_{j}$ ); see Table 2 for the coding of response items. We computed the frequency of academics' use of each type of engagement for the whole population in the following way:

$f_{j}=\frac{\sum_{n=1}^{N} b_{n, j}}{N}$

where $j$ is the type of industry engagement, $n$ is the individual and $N$ is the total sample after matching the different databases $(N=1895)$. We then constructed the academic engagement index by multiplying the number of times each academic had used each

\footnotetext{
1 This paper builds on a wider research project, which includes the following papers: Clarysse, Tartari, Salter, 2011; Tartari, Salter, D’Este, 2012; Tartari and Salter, 2013.
}

Table 2

Coding of occurrences of individuals' engagement.

\begin{tabular}{lllllr} 
Questionnaire answer (category) & 0 & $1-2$ & $3-5$ & $6-9$ & $>10$ \\
Occurrence $\left(b_{j}\right)$ & 0 & 1 & 1 & 1 & 1 \\
Volume of interaction $\left(T_{j}\right)$ & 0 & 1.5 & 4 & 7.5 & 10 \\
\hline
\end{tabular}

type of engagement $\left(T_{j}\right)$ and the frequency of its non-occurrence $\left(1-f_{j}\right)$, and summed the scores.

$I I I_{n}=\sum_{j=1}^{8} T_{j}\left(1-f_{j}\right)$

By considering the frequency with which each type of interaction is used in the overall population, the index takes account of the 'difficulty' of certain activities such as the creation of new physical facilities relative to others such as attending industry sponsored meetings. We extend the measure proposed by Bozeman and Gaughan (2007), using finer grained information that takes account of the actual number of occurrences of different types of engagement for every individual, as opposed only to occurrence.

In addition, to probe possible differences between the different kinds of engagement subsumed in the index, we created four variables representing four broad types of engagement: joint research, training collaboration, research services, and networking. The value for each of these broad types is represented by the average of the academics' use of two types of engagement with industry. Table 1 indicates the two subcomponents of each broad type.

\subsubsection{Independent variables}

Our main independent variable is departmental peers' industry engagement. Following Bercovitz and Feldman (2008), we define a peer as a departmental colleague of the same academic rank as the individual. We assume that among senior faculty members (e.g. professors), the decision to collaborate with industry will likely be influenced by the actions of their academic equals in the faculty. To avoid confounding effects deriving from authority-based relationships, we consider relationships only among similarly ranked individuals.

Our main independent variable peers' engagement is the average academic engagement of the individual's peers (excluding the focal individual). It is constructed based on data taken from our survey matched with departmental affiliation according to the RAE unit of assessment. A meaningful measure of peer behaviour requires information on at least one other researcher in addition to the focal individual. We excluded individuals with no data on peers, which left 1371 valid observations. The average cohort size in a department is 11 individuals, which is reassurance that our results are not driven by the behaviours of single researchers in small departments.

To explore the social comparison mechanisms inherent in peer effects, we interacted the main independent variable with the individual's academic age or number of years of experience as an academic, defined as the individual's present age minus age at $\mathrm{PhD}$ award. We interacted peers' engagement with a dummy variable for 
star scientists. In line with the literature on star scientists (Zucker and Darby, 1996, 2001; Azoulay et al., 2008), we define star scientist as academics in our sample in the top $1 \%$ of the distribution of citations in their discipline, and in the top $25 \%$ of the distribution for grants received from the EPSRC.

\subsubsection{Control variables}

We include a range of control variables to account for individual, department, university, and regional level effects on academic engagement with industry. To control for the academic's individual characteristics we included demographic characteristics such as gender and academic rank (coded as a dummy variable indicating professor status) (Link et al., 2007). We also included number of years of experience of working in the private sector (industry experience). We constructed dummy variables for British doctoral degree (British $P h D$ ) and a proxy for quality of the PhD awarding institution (elite $P h D$ ) based on inclusion in the Times Higher Education Supplement (2004) list of worldwide top universities. We included a variable for intrinsic motivation for becoming an academic researcher based on a question in the NSF Survey of Doctorate Holders about motivations related to research careers. Adherence to the traditional academic norms of openness might influence scientists' attitudes to collaboration. A study of 98 US professors conducted by Renault (2006) indicates that espousing the values of academic capitalism (as opposed to Mertonian values) is a strong predictor of involvement with industry. In controlling for motivation we partly address a potential sorting bias in our data (see below) because career motivations remains fairly stable over time and hence informs individuals' preference for specific types of work environments. The information for these control variables was taken from survey responses.

We control for researcher's quality and productivity. We include total research funding received from the EPSRC in the period 2000-2006, standardized by the average level of funding of other researchers in the same discipline (individual grants). We control for researcher's scientific productivity in the same period (2000-2006) based on number of publications on the ISI Web of Science identifying the researcher as an author (publications). We used a dummy variable to control for scientific discipline (basic discipline), identifying the disciplines mathematics, chemistry, and physics.

We used a group of variables to department's characteristics, taken from RAE 2008 data. Department industry funds refer to the departments' research income from industry in 2005-2007 per full time equivalent (FTE) staff. Although we were unable to observe the formal rules governing a department's industry collaboration, the amount of funding received from private companies acts as a proxy since we can expect that departments heavily funded by industry will encourage their members to collaborate with industry. We control for department research quality measured as the percentage of staff rated 'internationally leading' and 'international excellent' according to the RAE. These measures help to capture the opportunities for academic engagement afforded by the prestige and visibility of the individual's department.

To capture university characteristics we control for institutional involvement in commercialization and collaboration activities based on stock of university patents per FTE, and income from industry per employee (university industry funds) in the period 2005-2007. These variables measure the university's level of commercialization efforts, and the degree of institutionalized support for these activities (Landry et al., 2006). We assessed the profiles of the universities in the sample based on their RAE 2008 score (university research quality) and a dummy for group (Russell Group, Red Brick, 1994 Group, New Universities) to account for the strong institutional differences between groups of universities in the UK. Larger and more prestigious universities may afford more opportunities for industry collaboration than smaller, lower status institutions (Owen-Smith and Powell, 2001).

The last group of variables measures regional economic and innovation activity in the NUTS2 (37 UK regions) of the universities in our sample. We included variables for Gross Domestic Product (in $€$ millions) (region GDP), business R\&D expenditure (in $€$ millions) (region $R E D D$ ) and number of patent applications to the European Patent Office per million of inhabitants (region patents). These variables measure levels of demand for academic knowledge in the local environment (Krabel and Mueller, 2009).

\subsection{Identification strategy}

Empirical analysis of peer effects can produce spurious correlations, and may suffer from the identification problem described by Manski (1993). We dealt with these methodological issues as follows.

First, we addressed the possibility that local sorting processes for hiring and retaining academic staff and individual self-selection into departments might bias results. Keen industry collaborators might self-select into or be hired by departments with higher levels of academic engagement with industry. To address this we used information from grant records on moves between universities, extracting the researcher's previous two affiliations. We gathered information on level of industry-related activity in the origin and destination departments of these individuals based on funding received from industry according to RAE records. If the move was related to industry collaboration, we would expect some variation in the level of industry engagement between the origin and the destination departments. However, comparing the values for each individual based on a Wilcoxon signed-rank test, we found no statistically significant differences for level of income from industry received by the department of origin and the destination department $(z=-1.538$, Prob $>|z|=0.1241)$. It would seem that researchers do not move between departments based on the departments' industry collaboration profile, which suggests strongly that researchers do not self-select into departments for engagement reasons. This result holds for the subsample of 'highly engaged' academics (those in the top $25 \%$ or top $10 \%$ of the academic engagement index distribution). The data shows that academics move based on the research quality of the university and the department. The same test applied to the difference in research quality between origin and destination universities and departments, shows statistically significant differences (in both cases the destination is of higher quality on average). These tests do not completely exclude the possibility of a sorting effect based on the department's industry collaboration profiles. Even if we observe no differences in the level of engagement between the individual's origin and destination departments, we cannot exclude that researchers identify a desirable departmental match to industry engagement at the start of their careers and subsequently move to similar departments. However, our observation of the tendency to move to departments of higher scientific quality signals that the decision to select a specific department (or candidate) is driven mostly by scientific productivity considerations (Bercovitz and Feldman, 2007). This is particularly relevant in the UK context, where universities are periodically and publicly evaluated (and rewarded) on the basis of their scientific performance, assessed mostly on the basis of the quality of faculty members' scientific publications. These evaluations play a formative role in departments' hiring practices, leading to 'bidding wars' for leading faculty.

Second, the peer effect we want to measure should be truly endogenous, meaning the individual's behaviour will vary with the behaviour of the group to which s/he belongs. Simple observation of a correlation between individual and group behaviours may hide other mechanisms at play. A correlation effect might be due 
to unobservable characteristics influencing the behaviours of both the individual and his or her peers. Individuals might behave similarly to the group because of their similar individual characteristics. We addressed this problem by including detailed information on departments, universities and regions. We conducted an additional analysis aimed at reducing the effect of shared unobservable contextual characteristics on individual behaviour, following Bercovitz and Feldman (2008), including an independent variable outside peers' engagement, defined as the average value of the academic engagement index for individuals outside the focal individual's peer group, that is, for departmental colleagues of different ranks. This allows us to investigate whether the individual's decision to collaborate with industry is driven by unobservable department characteristics rather than imitating peers. To take account of 'outside peers', we require information on at least one additional individual in the same department, but of different seniority; this reduced the number of our observations to 1192 .

Third, we might be observing exogenous (contextual) effects: individual behaviour might be affected by exogenous characteristics - of peers (Manski, 2000). For instance, academic engagement might be based on the age and gender of co-workers. To control for this possibility, we computed the average academic age of the focal individual's peers (academic age peers) and included it in the model.

Fourth, average group behaviour might be influenced by the behaviour of the individual member, introducing a 'reflection problem' (Manski, 1993, 2000). Manski suggests that the reflection problem can be alleviated by examining peer effects on the basis of attitudes and perceptions rather than manifested behaviours: this makes it easier to differentiate between preferences interaction and expectations interaction (Manski, 1993, 2000). We performed an analysis using a perception variable measuring the extent of the benefits of academic engagement perceived by the individual's peers. We operationalized the extent of the perceived benefits from industry collaboration as the total number of single benefits indicated by the individual as 'important' or 'very important' in the questionnaire (items reported in Appendix). The list of benefits builds on D'Este and Patel (2007) and refers to both personal and professional benefits from working with industry. This information allowed us to construct a peers' benefits measure based on the average number of benefits perceived by the individual's departmental peers (excluding the focal individual). Subjective evaluation of the benefits of industry engagement helps to mitigate some of the measurement issues associated with the reflection problem (Manski, 1993). Manski (2000) states that, so far, 'the practice has been to infer interaction processes from observations of their outcomes. [...] Experimental and subjective data will have to play important roles in future efforts to learn about social interactions'.

We address the issue of reflection by isolating the behaviour of recently recruited academics. Sorensen (2006) in an analysis of social learning and health plan choices assumes that the health plan choices of newly hired employees are influenced by co-workers, but not vice versa. Our data allowed us to perform an analysis making a similar assumption. Among the individuals in our sample, 523 had responded to the 2004 survey, which allowed us to identify individuals (52) who had moved universities between 2004 and 2009. They were labelled movers and assumed to be influenced by the behaviour of their new colleagues, but not vice versa since the observation period was too short for the reflection mechanism to have occurred.

\subsection{Estimation}

We employed an ordinary least squares (OLS) model to investigate the impact of peers' behaviour on individual industry collaboration. Use of OLS assumes a normally distributed dependent variable: therefore, we employ the natural logarithm of the academic engagement index. To address possible heteroschedasticity problems, we use robust standard errors. Another assumption of OLS is that standard errors are independently and identically distributed; however, this can be violated. If the errors are clustered (i.e. if the observations within a certain group are correlated in unobservable ways), the OLS estimates will be unbiased, but the standard errors may be wrong, leading to incorrect inferences. Since the respondents in our sample are affiliated to different disciplines, we can expect some group correlation which we are not able to observe; therefore, we clustered errors by scientific discipline. As a robustness check, we clustered errors also by department and university; the main results were unchanged.

\section{Results}

Tables 3 and 4 present the descriptive statistics and correlations for all the variables employed. Correlations are generally low to moderate indicating that multicollinearity is not a problem in the estimations. The variance inflation factor for the main specification is 2.4 , which is well below the value of 10 commonly recognized as indicating multicollinearity. The appropriateness of using weights for the academic engagement index can be gauged from the pattern of academics' engagement across different disciplines. Some activities are more common than others. For example, nearly $83 \%$ of respondents attended conferences with industry participation while only $17 \%$ were involved in the creation of physical facilities, such as laboratories, with industry partners. Eight percent of our sample had not engaged in any form of industry collaboration, and a small proportion of individuals did not perceive any important benefits from industry engagement. Additional research funding was seen as the most important driver for industry collaboration.

Table 5 presents the results of our econometric analyses. Model (1) is the baseline model in which the dependent variable is academic engagement. Academic age has a negative and statistically significant effect on the level of engagement with industry. Bercovitz and Feldman (2008) observed that a longer time since completion of formal training reduced the likelihood of the researcher collaborating with industry because, in the past, engagement with industry was less relevant or even discouraged. Being a professor (academic rank $=1$ ) has a positive and statistically significant effect: this finding is in line with previous research (Link et al., 2007) and suggests that more experienced academics command more organizational resources and have more freedom to engage in proactive behaviours such as collaboration with industry. Experience of working in the private sector (industry experience) is positive and significant, which is in line with previous research (Audretsch, 1998). Intrinsic motivation to become an academic is positively and significantly related to industry engagement, which perhaps indicates that academics who adhere to the norms of public science collaborate with industry in order to advance their research agendas (D'Este and Perkmann, 2011). Academics who graduated from a UK university are significantly more likely to engage with industry than those trained abroad, but a PhD degree from a highstatus university (elite $P h D$ ) seems not to have an effect. Being a high-performing scientist (star) is not significant in the regression, suggesting that the positive and significant correlation between research productivity and both academic engagement and commercialization found in previous studies of life scientists (Zucker and Darby, 1996) may not hold for physical and engineering scientists. Analysing individuals' scientific productivity in more depth we find that the effect of the amount of EPSRC grant funding received on industry engagement is not statistically significant, while number of publications is positively and significantly correlated with industry collaboration, which is in line with previous 
Table 3

Descriptive statistics.

\begin{tabular}{|c|c|c|c|c|c|}
\hline Variable & Obs & Mean & Std. Dev. & Min & Max \\
\hline Individual engagement & 1371 & 4.43 & 4.43 & 0 & 33.01 \\
\hline Gender & 1371 & 0.11 & 0.31 & 0 & 1 \\
\hline Academic age & 1371 & 21.07 & 9.87 & 1 & 60 \\
\hline Academic rank & 1371 & 0.54 & 0.50 & 0 & 1 \\
\hline Industry experience & 1371 & 2.77 & 5.26 & 0 & 45 \\
\hline Star scientist & 1371 & 0.08 & 0.31 & 0 & 3 \\
\hline Intrinsic motivation & 1371 & 3.35 & 0.80 & 0 & 4 \\
\hline British PhD & 1371 & 0.84 & 0.37 & 0 & 1 \\
\hline Elite PhD & 1371 & 0.42 & 0.49 & 0 & 1 \\
\hline Individual grants & 1371 & 1.00 & 2.04 & 0 & 27.28 \\
\hline Publications & 1371 & 25.03 & 27.04 & 0 & 393 \\
\hline Basic discipline & 1371 & 0.39 & 0.49 & 0 & 1 \\
\hline Russell Group & 1371 & 0.62 & 0.49 & 0 & 1 \\
\hline Red Brick Universities & 1371 & 0.18 & 0.38 & 0 & 1 \\
\hline Group 1994 Universities & 1371 & 0.19 & 0.40 & 0 & 1 \\
\hline New Universities & 1371 & 0.03 & 0.16 & 0 & 1 \\
\hline Department industry funds (per employee) & 1371 & 179,925 & 125,988 & 3416 & 993,625 \\
\hline Dept. research quality & 1371 & 0.63 & 0.15 & 0.11 & 0.95 \\
\hline University patents (per employee) & 1371 & 0.25 & 0.30 & 0 & 1.24 \\
\hline University industry funds (per employee) & 1371 & 24.08 & 23.69 & 1.15 & 142.81 \\
\hline Univ. research quality & 1371 & 2.68 & 0.19 & 1.75 & 2.98 \\
\hline Region GDP (Million Euro) & 1371 & 73,013 & 55,214 & 17,117 & 193,752 \\
\hline Region R\&D (by GDP) & 1371 & 1.78 & 0.97 & 0.93 & 4.29 \\
\hline Region patents (per million inhabitants) & 1371 & 77 & 58 & 0.07 & 199 \\
\hline Peers' engagement & 1371 & 4.48 & 3.24 & 0 & 33.01 \\
\hline Outside peers' engagement & 1229 & 4.42 & 3.12 & 0 & 33.01 \\
\hline Peers' academic age & 1371 & 18.82 & 8.91 & 0 & 49 \\
\hline Peers' benefits & 1371 & 6.08 & 2.70 & 0 & 15 \\
\hline
\end{tabular}

research on academic inventors (Agrawal and Henderson, 2002; Azoulay et al., 2007; Breschi et al., 2007; Fabrizio and Di Minin, 2008). Working within a basic discipline has a negative and significant effect on engagement, which confirms previous results (Link et al., 2007). None of the department level variables has a significant effect. University quality is negatively and significantly correlated with engagement: better universities receive more government funding and more funding from a wider range of other sources and, therefore, are less reliant on industry to finance research projects. None of the regional level variables is significant in the regression.

Model (2) builds on the previous base model specification, but includes peers' engagement, the variable measuring the level of engagement of the individual's departmental peers. The explanatory power of the model is significantly strengthened with the addition of the main independent variable: $R^{2}$ increases from 0.193 to 0.239 . The influence of the peers' engagement with industry is positive and significant, suggesting that the collaboration activities of an academic mirror the behaviour of his/her departmental colleagues of the same rank, as predicted by $\mathrm{H} 1$. All the control variables show the same effect as in the baseline model.

In Model (3) we introduce the first moderator, academic age, which again improves the model's explanatory power. The interaction term is significant and negative: Younger individuals rely more heavily than their senior colleagues on social comparison with their peers when deciding on engagement with industry, which confirms H2. In Model (4), we test H3 by including the second moderator, star scientist. As expected, the interaction term between star scientist and peers' engagement is negative and significant: high-status individuals compare themselves less with their departmental peers and therefore are less locally conformist. Again, the change in $R^{2}$ is positive and significant although the coefficient of the interaction term is significant only at the $10 \%$ level. Finally, in Model (5), we test the full model. The signs are consistent with the previous specifications, and we observe a statistically significant increase in $R^{2}$. As a robustness check, we calculated an alternative specification of the main model that included university dummies and region dummies instead of the university and regional variables; the main results did not change.
Table 6 presents the analysis testing for possible sources of spurious correlation. Model (1) reproduces the main model testing the influence of peers' behaviours on individual behaviours as a reference. To check for unobserved heterogeneity, which might explain the correlation between behaviours for other reasons than peer imitation, in Model (2), along with the main independent variable, we introduce an additional variable measuring outside peers' engagement. In this specification, the coefficients of the main independent variable and the controls remain unchanged, while the coefficient of outside peers' engagement is not significant. 'Outside peers' comprises all individuals within a department of different rank to the focal individual. This suggests our results are driven by the identified peer effects and not by some characteristics of the department we could not control for.

To rule out the possibility of contextual (exogenous) effects in the analysis, in Model (3) we introduce the average academic age of the focal individual's peers. As expected, the coefficient of peers' academic age is not significant: individual decisions related to industry engagement activities are not influenced by a key exogenous characteristic of the individual's co-workers.

Models (4) and (5) address the problem of reflection. Following Manski's $(1993,2000)$ suggestion we test the effect of peers' perceptions of the benefits deriving from academic engagement (as opposed to manifest behaviours) on the focal individual's engagement. We find the effect of peers' perception of the benefits on individual engagement is positive and significant. An individual's behaviour is driven not only by what peers do but also by what they believe. Beliefs tend to be more stable than behaviours and, hence, individuals will be less likely to be affected by others' behaviours. This finding provides additional evidence of the presence of genuine peer effects because it makes it less likely that our findings are afflicted by reverse causality in the sense that peers could be influenced by the focal individual's behaviour.

Model (5) is a standard analysis of the subsample of researchers who moved universities between 2004 and 2009. The coefficient associated with peers' behaviour is significant and positive, providing additional support for the argument that individual behaviour is shaped by peers' behaviour and not vice versa, assuming that 
Table 4

Correlation matrix.

\begin{tabular}{|c|c|c|c|c|c|c|c|c|c|c|c|c|c|}
\hline & [1] & [2] & [3] & [4] & [5] & [6] & [7] & [8] & [9] & [10] & [11] & [12] & [13] \\
\hline [1] Gender & 1 & & & & & & & & & & & & \\
\hline [2] Academic age & -0.1453 & 1 & & & & & & & & & & & \\
\hline [3] Academic rank & -0.1175 & 0.4923 & 1 & & & & & & & & & & \\
\hline [4] Industry experience & -0.0667 & 0.1722 & 0.0684 & 1 & & & & & & & & & \\
\hline [5] Star scientist & -0.0165 & 0.0961 & 0.2280 & 0.0551 & 1 & & & & & & & & \\
\hline [6] Intrinsic motivation & 0.0963 & -0.0041 & 0.0497 & -0.0792 & 0.0259 & 1 & & & & & & & \\
\hline [7] British PhD & -0.0545 & 0.1551 & 0.0515 & 0.0860 & 0.0660 & -0.0076 & 1 & & & & & & \\
\hline [8] Elite PhD & -0.0212 & 0.0451 & 0.0381 & 0.0015 & 0.0815 & 0.0351 & 0.1420 & 1 & & & & & \\
\hline [9] Individual grants & -0.0512 & 0.1459 & 0.1986 & 0.0532 & 0.3587 & -0.0198 & 0.0981 & 0.0742 & 1 & & & & \\
\hline [10] Publications & -0.0509 & 0.1826 & 0.2918 & -0.0019 & 0.4014 & 0.0487 & 0.0528 & 0.0756 & 0.1566 & 1 & & & \\
\hline [11] Basic discipline & -0.0064 & 0.0566 & 0.0404 & -0.1075 & -0.0385 & 0.0133 & -0.0506 & 0.1288 & -0.0121 & 0.1340 & 1 & & \\
\hline [12] Russell Group & 0.0016 & 0.0278 & 0.0431 & -0.0855 & 0.1302 & 0.0717 & 0.0038 & 0.1904 & 0.0707 & 0.1305 & 0.0854 & 1 & \\
\hline [13] Red Brick Universities & -0.0444 & 0.0114 & -0.0389 & -0.0329 & 0.0346 & 0.0277 & 0.0595 & 0.0055 & -0.0205 & 0.0081 & 0.0094 & 0.3527 & 1 \\
\hline [14] Group 1994 & -0.0427 & 0.0006 & -0.0241 & 0.0491 & -0.0866 & -0.0360 & -0.0131 & -0.0752 & -0.0561 & -0.0417 & 0.0500 & -0.6605 & -0.2329 \\
\hline [15] New Universities & 0.0103 & -0.0205 & -0.0008 & 0.0261 & -0.0045 & 0.0178 & 0.0592 & -0.0300 & -0.0232 & -0.0415 & -0.0927 & -0.1783 & -0.0629 \\
\hline [16] Dept. industry funds & -0.0436 & 0.0738 & 0.0699 & 0.0381 & 0.0456 & 0.0737 & 0.0334 & 0.0627 & 0.0912 & 0.2291 & 0.2435 & 0.2523 & 0.0946 \\
\hline [17] Dept. research quality & -0.0140 & -0.0046 & 0.0047 & 0.0255 & 0.1488 & 0.0098 & 0.0162 & 0.1600 & 0.0967 & 0.0655 & -0.1982 & 0.4554 & 0.1171 \\
\hline [18] Univ. Patents & 0.0494 & -0.0249 & -0.0221 & -0.0050 & 0.0511 & 0.0034 & -0.0477 & 0.1063 & 0.0246 & 0.0193 & -0.0021 & 0.2429 & -0.2152 \\
\hline [19] Univ. industry funds & 0.0436 & 0.0080 & 0.0095 & 0.0821 & 0.0194 & -0.0544 & 0.0273 & 0.0341 & 0.0412 & -0.0190 & -0.1202 & -0.0385 & -0.1533 \\
\hline [20] Univ. research quality & -0.0172 & 0.0370 & 0.0135 & -0.0530 & 0.1044 & 0.0511 & -0.0260 & 0.2904 & 0.0509 & 0.1332 & 0.1395 & 0.5981 & 0.0111 \\
\hline [21] Region GDP & 0.1017 & -0.0258 & -0.0046 & -0.0373 & 0.0319 & 0.0516 & -0.0495 & 0.1399 & 0.0043 & -0.0376 & 0.0534 & 0.1838 & -0.2235 \\
\hline [22] Region R\&D & -0.0132 & 0.0259 & 0.0214 & 0.0487 & 0.0456 & -0.0159 & 0.0278 & 0.0908 & 0.0606 & 0.0895 & -0.0594 & -0.0578 & -0.1956 \\
\hline [23] Region patents & 0.0329 & 0.0290 & 0.0152 & -0.0398 & 0.0737 & 0.0486 & -0.0055 & 0.2331 & 0.0401 & 0.1024 & 0.1123 & 0.2667 & -0.2312 \\
\hline [24] Peers' engagement & 0.0023 & 0.0720 & 0.2289 & 0.1071 & 0.0780 & -0.0016 & 0.0900 & -0.0478 & 0.0778 & 0.1072 & -0.2465 & -0.0584 & -0.0113 \\
\hline [25] Outside peers' engagement & 0.0057 & -0.0665 & -0.2668 & 0.0785 & -0.0266 & 0.0053 & 0.0644 & -0.0697 & -0.0472 & -0.0652 & -0.2374 & -0.1278 & -0.0403 \\
\hline \multirow[t]{2}{*}{ [26] Peers' academic age } & -0.1007 & 0.4313 & 0.6458 & 0.0250 & 0.1815 & 0.0611 & 0.0634 & 0.0173 & 0.1259 & 0.2192 & 0.0386 & 0.0435 & 0.0169 \\
\hline & [14] & [15] & [16] & [17] & [18] & [19] & [20] & [21] & [22] & [23] & [24] & [25] & [26] \\
\hline \multicolumn{14}{|l|}{ [1] Gender } \\
\hline \multicolumn{14}{|l|}{ [2] Academic age } \\
\hline \multicolumn{14}{|l|}{ [3] Academic rank } \\
\hline \multicolumn{14}{|l|}{ [4] Industry experience } \\
\hline \multirow{2}{*}{\multicolumn{14}{|c|}{$\begin{array}{l}\text { [5] Star scientist } \\
\text { [6] Intrinsic motivation }\end{array}$}} \\
\hline & & & & & & & & & & & & & \\
\hline \multicolumn{14}{|l|}{ [7] British PhD } \\
\hline \multicolumn{14}{|l|}{ [8] Elite PhD } \\
\hline \multirow{2}{*}{\multicolumn{14}{|c|}{$\begin{array}{l}\text { [9] Individual grants } \\
\text { [10] Publications }\end{array}$}} \\
\hline & & & & & & & & & & & & & \\
\hline \multicolumn{14}{|l|}{ [11] Basic discipline } \\
\hline \multicolumn{14}{|l|}{ [12] Russell Group } \\
\hline \multicolumn{14}{|l|}{ [13] Red Brick Universities } \\
\hline [14] Group 1994 & 1 & & & & & & & & & & & & \\
\hline [15] New Universities & -0.0675 & 1 & & & & & & & & & & & \\
\hline [16] Dept. industry funds & -0.1082 & -0.0825 & 1 & & & & & & & & & & \\
\hline [17] Dept. research quality & -0.1554 & -0.2174 & 0.1504 & 1 & & & & & & & & & \\
\hline [18] Univ. Patents & -0.2522 & -0.0264 & 0.1381 & 0.1755 & 1 & & & & & & & & \\
\hline [19] Univ. industry funds & -0.1160 & -0.0538 & 0.0714 & 0.0703 & 0.4851 & 1 & & & & & & & \\
\hline [20] Univ. research quality & -0.0937 & -0.4209 & 0.2357 & 0.6119 & 0.3151 & 0.0548 & 1 & & & & & & \\
\hline [21] Region GDP & -0.1325 & -0.0250 & 0.0452 & 0.0794 & 0.6222 & 0.2503 & 0.3242 & 1 & & & & & \\
\hline [22] Region R\&D & 0.0451 & -0.0475 & -0.0083 & 0.1536 & -0.1874 & 0.3078 & 0.1816 & -0.2383 & 1 & & & & \\
\hline [23] Region patents & 0.0008 & -0.0623 & 0.0481 & 0.3060 & 0.1936 & 0.0507 & 0.5988 & 0.4232 & 0.4818 & 1 & & & \\
\hline [24] Peers' engagement & -0.0226 & -0.0048 & 0.0954 & 0.0469 & 0.0392 & 0.2276 & -0.0812 & -0.0487 & 0.0734 & -0.0873 & 1 & & \\
\hline [25] Outside peers' engagement & -0.0103 & 0.0777 & 0.0497 & -0.0258 & 0.0665 & 0.2111 & -0.1212 & -0.0111 & 0.0212 & -0.1014 & 0.1434 & 1 & \\
\hline [26] Peers' academic age & -0.0312 & 0.0256 & 0.0527 & -0.0422 & -0.0484 & -0.0075 & 0.0114 & -0.0021 & 0.0059 & 0.0609 & 0.0875 & -0.0929 & 1 \\
\hline
\end{tabular}


Table 5

Regression results for individual academic engagement. Dependent variable: Academic engagement index.

\begin{tabular}{|c|c|c|c|c|c|}
\hline Variables & (1) & $(2)$ & (3) & (4) & $(5)$ \\
\hline Gender & $\begin{array}{l}-0.0331 \\
(0.044)\end{array}$ & $\begin{array}{l}-0.0466 \\
(0.042)\end{array}$ & $\begin{array}{l}-0.0375 \\
(0.044)\end{array}$ & $\begin{array}{l}-0.0478 \\
(0.041)\end{array}$ & $\begin{array}{l}-0.0388 \\
(0.043)\end{array}$ \\
\hline Academic age & $\begin{array}{l}-0.0072^{* *} \\
(0.002)\end{array}$ & $\begin{array}{l}-0.0061^{*} \\
(0.002)\end{array}$ & $\begin{array}{l}-0.0059^{*} \\
(0.002)\end{array}$ & $\begin{array}{l}-0.0062^{*} \\
(0.002)\end{array}$ & $\begin{array}{l}-0.0059^{* *} \\
(0.002)\end{array}$ \\
\hline Academic rank & $\begin{array}{l}0.2377^{* * *} \\
(0.042)\end{array}$ & $\begin{array}{l}0.1496^{* * *} \\
(0.034)\end{array}$ & $\begin{array}{l}0.1431^{* * *} \\
(0.033)\end{array}$ & $\begin{array}{l}0.1479^{* * *} \\
(0.033)\end{array}$ & $\begin{array}{l}0.1416^{* * *} \\
(0.032)\end{array}$ \\
\hline Industry experience & $\begin{array}{l}0.0240^{* * * *} \\
(0.004)\end{array}$ & $\begin{array}{l}0.0229^{* * *} \\
(0.004)\end{array}$ & $\begin{array}{l}0.0232^{* * *} \\
(0.004)\end{array}$ & $\begin{array}{l}0.0229^{* * *} \\
(0.004)\end{array}$ & $\begin{array}{l}0.0231^{* * *} \\
(0.004)\end{array}$ \\
\hline Star scientist & $\begin{array}{l}-0.0952 \\
(0.091)\end{array}$ & $\begin{array}{l}-0.0761 \\
(0.090)\end{array}$ & $\begin{array}{l}-0.0738 \\
(0.092)\end{array}$ & $\begin{array}{l}-0.0621 \\
(0.100)\end{array}$ & $\begin{array}{l}-0.0609 \\
(0.100)\end{array}$ \\
\hline Intrinsic motivation & $\begin{array}{l}0.0952^{* *} \\
(0.028)\end{array}$ & $\begin{array}{l}0.0916 \\
(0.027)\end{array}$ & $\begin{array}{l}0.0915^{* *} \\
(0.028)\end{array}$ & $\begin{array}{l}0.0918^{* *} \\
(0.027)\end{array}$ & $\begin{array}{l}0.0917^{* *} \\
(0.028)\end{array}$ \\
\hline British PhD & $\begin{array}{l}0.2172^{* *} \\
(0.069)\end{array}$ & $\begin{array}{l}0.1899 \\
(0.069)\end{array}$ & $\begin{array}{l}0.1847^{*} \\
(0.069)\end{array}$ & $\begin{array}{l}0.1894 \\
(0.069)\end{array}$ & $\begin{array}{l}0.1843^{*} \\
(0.069)\end{array}$ \\
\hline Elite PhD & $\begin{array}{l}-0.0736 \\
(0.048)\end{array}$ & $\begin{array}{l}-0.0716^{+} \\
(0.038)\end{array}$ & $\begin{array}{l}-0.0690^{+} \\
(0.036)\end{array}$ & $\begin{array}{l}-0.0721^{+} \\
(0.037)\end{array}$ & $\begin{array}{l}-0.0695^{+} \\
(0.036)\end{array}$ \\
\hline Individual grants & $\begin{array}{l}0.0123 \\
(0.019)\end{array}$ & $\begin{array}{l}0.0105 \\
(0.018)\end{array}$ & $\begin{array}{l}0.0102 \\
(0.018)\end{array}$ & $\begin{array}{l}0.0113 \\
(0.018)\end{array}$ & $\begin{array}{l}0.0110 \\
(0.018)\end{array}$ \\
\hline Publications & $\begin{array}{l}0.0033^{*} \\
(0.001)\end{array}$ & $\begin{array}{l}0.0029^{*} \\
(0.001)\end{array}$ & $\begin{array}{l}0.0028^{*} \\
(0.001)\end{array}$ & $\begin{array}{l}0.0029^{*} \\
(0.001)\end{array}$ & $\begin{array}{l}0.0029^{*} \\
(0.001)\end{array}$ \\
\hline Basic discipline & $\begin{array}{l}-0.3202^{*} \\
(0.134)\end{array}$ & $\begin{array}{l}-0.2404^{*} \\
(0.097)\end{array}$ & $\begin{array}{l}-0.2417^{*} \\
(0.098)\end{array}$ & $\begin{array}{l}-0.2413^{*} \\
(0.098)\end{array}$ & $\begin{array}{l}-0.2425^{*} \\
(0.099)\end{array}$ \\
\hline Dept. industry funds (per employee) & $\begin{array}{l}0.0000 \\
(0.000)\end{array}$ & $\begin{array}{l}0.0000 \\
(0.000)\end{array}$ & $\begin{array}{l}0.0000 \\
(0.000)\end{array}$ & $\begin{array}{l}0.0000 \\
(0.000)\end{array}$ & $\begin{array}{l}0.0000 \\
(0.000)\end{array}$ \\
\hline Dept. research quality & $\begin{array}{l}0.1310 \\
(0.273)\end{array}$ & $\begin{array}{l}0.0652 \\
(0.182)\end{array}$ & $\begin{array}{l}0.0698 \\
(0.180)\end{array}$ & $\begin{array}{l}0.0593 \\
(0.179)\end{array}$ & $\begin{array}{l}0.0643 \\
(0.178)\end{array}$ \\
\hline University patents & $\begin{array}{l}0.0392 \\
(0.126)\end{array}$ & $\begin{array}{l}0.0465 \\
(0.107)\end{array}$ & $\begin{array}{l}0.0398 \\
(0.107)\end{array}$ & $\begin{array}{l}0.0501 \\
(0.106)\end{array}$ & $\begin{array}{l}0.0433 \\
(0.107)\end{array}$ \\
\hline Univ. industry funds (per employee) & $\begin{array}{l}0.0036^{*} \\
(0.002)\end{array}$ & $\begin{array}{l}0.0021^{+} \\
(0.001)\end{array}$ & $\begin{array}{l}0.0022^{+} \\
(0.001)\end{array}$ & $\begin{array}{l}0.0021^{+} \\
(0.001)\end{array}$ & $\begin{array}{l}0.0022^{+} \\
(0.001)\end{array}$ \\
\hline Univ. research quality & $\begin{array}{l}-0.4514^{+} \\
(0.233)\end{array}$ & $\begin{array}{l}-0.3662^{*} \\
(0.163)\end{array}$ & $\begin{array}{l}-0.3817^{*} \\
(0.158)\end{array}$ & $\begin{array}{l}-0.3662^{*} \\
(0.160)\end{array}$ & $\begin{array}{l}-0.3813^{*} \\
(0.156)\end{array}$ \\
\hline Region GDP & $\begin{array}{l}0.0000 \\
(0.000)\end{array}$ & $\begin{array}{l}0.0000 \\
(0.000)\end{array}$ & $\begin{array}{l}0.0000 \\
(0.000)\end{array}$ & $\begin{array}{l}0.0000 \\
(0.000)\end{array}$ & $\begin{array}{l}0.0000 \\
(0.000)\end{array}$ \\
\hline Region R\&D & $\begin{array}{l}0.0188 \\
(0.050)\end{array}$ & $\begin{array}{l}0.0213 \\
(0.042)\end{array}$ & $\begin{array}{l}0.0196 \\
(0.041)\end{array}$ & $\begin{array}{l}0.0203 \\
(0.042)\end{array}$ & $\begin{array}{l}0.0187 \\
(0.041)\end{array}$ \\
\hline Region patents & $\begin{array}{l}-0.0002 \\
(0.001)\end{array}$ & $\begin{array}{l}-0.0002 \\
(0.001)\end{array}$ & $\begin{array}{l}-0.0002 \\
(0.001)\end{array}$ & $\begin{array}{l}-0.0002 \\
(0.001)\end{array}$ & $\begin{array}{l}-0.0002 \\
(0.001)\end{array}$ \\
\hline Peers' engagement & & $\begin{array}{l}0.1811^{* * *} \\
(0.034)\end{array}$ & $\begin{array}{l}0.3021^{* * *} \\
(0.049)\end{array}$ & $\begin{array}{l}0.1893^{* * *} \\
(0.033)\end{array}$ & $\begin{array}{l}0.3075^{* * *} \\
(0.048)\end{array}$ \\
\hline Academic age $\times$ peers' engagement & & & $\begin{array}{l}-0.0055^{* *} \\
(0.002)\end{array}$ & & $\begin{array}{l}-0.0054^{* *} \\
(0.002)\end{array}$ \\
\hline Star scientist $\times$ peers' engagement & & & & $\begin{array}{l}-0.0891^{+} \\
(0.043)\end{array}$ & $\begin{array}{l}-0.0820^{+} \\
(0.045)\end{array}$ \\
\hline Constant & $\begin{array}{l}1.8182^{* *} \\
(0.513)\end{array}$ & $\begin{array}{l}1.7130^{* * *} \\
(0.360)\end{array}$ & $\begin{array}{l}1.7552^{* * *} \\
(0.349)\end{array}$ & $\begin{array}{l}1.7163^{* * *} \\
(0.357)\end{array}$ & $\begin{array}{l}1.7575^{* * *} \\
(0.346)\end{array}$ \\
\hline Observations & 1371 & 1371 & 1371 & 1371 & 1371 \\
\hline$R$-squared & 0.193 & 0.239 & 0.244 & 0.240 & 0.245 \\
\hline
\end{tabular}

Notes: Ordinary Least Squares, robust standard errors clustered by discipline. University groups included.

Two-tailed tests.

$+p<0.10$.

${ }^{*} p<0.05$.

${ }^{* *} p<0.01$

**** $p<0.001$.

recent movers are more likely to be influenced by their colleagues and that the time frame is too short for the mean behaviour of the group to be influenced by these new colleagues.

In order to control for the possibility that these effects are generated by social comparison with peers and not by a hierarchical imposition of policy, we control for whether junior researchers' engagement with industry behaviour is influenced by the engagement of the senior departmental colleagues. In Table 6 we estimate a similar model to Model (2) for the subsample of junior researchers: in this case, the coefficient of the variable 'outside peers' behaviour' should show the effect of more senior colleagues' behaviour on junior researchers' behaviour. We found no effect. This would suggest that junior researchers are not significantly influenced by the behaviour of senior colleagues, but are significantly influenced by colleagues of the same rank.
To explore whether peer effects differ across different kinds of industry engagement, we computed the main regression model using the four broad types of engagement as the dependent variables (see results in Table 7). While we observe a decrease in the significance of the coefficients and in the $R^{2}$ due to a decrease in the likelihood of observing a specific behaviour, the results are virtually unchanged. It seems, therefore, that social comparison mechanisms apply across the whole range of collaboration activities. To account for the possibility that the four regressions are not independent of each other and that the residuals might be correlated, we computed them using a seemingly unrelated regressions (SUR) model which allows the error terms in the four regressions to be correlated with each other. The results do not change.

While similar versions of our dependent variable have been previously used (Bozeman and Gaughan, 2007; Aschhoff and Grimpe, 
Table 6

Regression results for tests for the identification problems. Dependent variable: Academic engagement index.

\begin{tabular}{|c|c|c|c|c|c|}
\hline Variables & (1) & $(2)$ & (3) & (4) & $(5)$ \\
\hline Gender & $\begin{array}{l}-0.0466 \\
(0.042)\end{array}$ & $\begin{array}{l}-0.0548 \\
(0.039)\end{array}$ & $\begin{array}{l}-0.0459 \\
(0.043)\end{array}$ & $\begin{array}{l}-0.0546 \\
(0.041)\end{array}$ & $\begin{array}{l}-0.0316 \\
(0.332)\end{array}$ \\
\hline Academic age & $\begin{array}{l}-0.0061^{*} \\
(0.002)\end{array}$ & $\begin{array}{l}-0.0054^{*} \\
(0.002)\end{array}$ & $\begin{array}{l}-0.0062^{*} \\
(0.002)\end{array}$ & $\begin{array}{l}-0.0064^{* *} \\
(0.002)\end{array}$ & $\begin{array}{l}0.0229 \\
(0.018)\end{array}$ \\
\hline Academic rank & $\begin{array}{l}0.1496^{* * *} \\
(0.034)\end{array}$ & $\begin{array}{l}0.1572^{* * *} \\
(0.034)\end{array}$ & $\begin{array}{l}0.1418^{* * *} \\
(0.037)\end{array}$ & $\begin{array}{l}0.1607^{* * *} \\
(0.033)\end{array}$ & $\begin{array}{l}-0.1271 \\
(0.355)\end{array}$ \\
\hline Industry experience & $\begin{array}{l}0.0229^{* * * *} \\
(0.004)\end{array}$ & $\begin{array}{l}0.0200^{* * * *} \\
(0.003)\end{array}$ & $\begin{array}{l}0.0230^{* * *} \\
(0.004)\end{array}$ & $\begin{array}{l}0.0226^{* * *} \\
(0.004)\end{array}$ & $\begin{array}{l}0.0039 \\
(0.028)\end{array}$ \\
\hline Star scientist & $\begin{array}{l}-0.0761 \\
(0.090)\end{array}$ & $\begin{array}{l}-0.0799 \\
(0.087)\end{array}$ & $\begin{array}{l}-0.0767 \\
(0.090)\end{array}$ & $\begin{array}{l}-0.0695 \\
(0.089)\end{array}$ & $\begin{array}{l}0.1788 \\
(0.357)\end{array}$ \\
\hline Intrinsic motivation & $\begin{array}{l}0.0916^{* *} \\
(0.027)\end{array}$ & $\begin{array}{l}0.0904^{* *} \\
(0.023)\end{array}$ & $\begin{array}{l}0.0913^{* *} \\
(0.027)\end{array}$ & $\begin{array}{l}0.0858^{* *} \\
(0.027)\end{array}$ & $\begin{array}{l}0.1386 \\
(0.155)\end{array}$ \\
\hline British PhD & $\begin{array}{l}0.1899^{*} \\
(0.069)\end{array}$ & $\begin{array}{l}0.1793^{*} \\
(0.067)\end{array}$ & $\begin{array}{l}0.1897^{*} \\
(0.068)\end{array}$ & $\begin{array}{l}0.1856^{*} \\
(0.069)\end{array}$ & $\begin{array}{l}0.1833 \\
(0.258)\end{array}$ \\
\hline Elite PhD & $\begin{array}{l}-0.0716^{+} \\
(0.038)\end{array}$ & $\begin{array}{l}-0.0473 \\
(0.036)\end{array}$ & $\begin{array}{l}-0.0714^{+} \\
(0.038)\end{array}$ & $\begin{array}{l}-0.0669 \\
(0.038)\end{array}$ & $\begin{array}{l}0.2099 \\
(0.254)\end{array}$ \\
\hline Individual grants & $\begin{array}{l}0.0105 \\
(0.018)\end{array}$ & $\begin{array}{l}0.0088 \\
(0.017)\end{array}$ & $\begin{array}{l}0.0106 \\
(0.018)\end{array}$ & $\begin{array}{l}0.0115 \\
(0.018)\end{array}$ & $\begin{array}{l}0.0056 \\
(0.102)\end{array}$ \\
\hline Publications & $\begin{array}{l}0.0029^{*} \\
(0.001)\end{array}$ & $\begin{array}{l}0.0027^{*} \\
(0.001)\end{array}$ & $\begin{array}{l}0.0029^{*} \\
(0.001)\end{array}$ & $\begin{array}{l}0.0029^{*} \\
(0.001)\end{array}$ & $\begin{array}{l}-0.0040 \\
(0.008)\end{array}$ \\
\hline Basic discipline & $\begin{array}{l}-0.2404^{*} \\
(0.097)\end{array}$ & $\begin{array}{l}-0.2263^{*} \\
(0.088)\end{array}$ & $\begin{array}{l}-0.2403^{*} \\
(0.097)\end{array}$ & $\begin{array}{l}-0.2160^{*} \\
(0.088)\end{array}$ & $\begin{array}{l}-0.3643 \\
(0.234)\end{array}$ \\
\hline Dpt. industry funds (per employee) & $\begin{array}{l}0.0000 \\
(0.000)\end{array}$ & $\begin{array}{l}0.0000 \\
(0.000)\end{array}$ & $\begin{array}{l}0.0000 \\
(0.000)\end{array}$ & $\begin{array}{l}0.0000 \\
(0.000)\end{array}$ & $\begin{array}{l}0.0000^{* * *} \\
(0.000)\end{array}$ \\
\hline Dept. research quality & $\begin{array}{l}0.0652 \\
(0.182)\end{array}$ & $\begin{array}{l}-0.0621 \\
(0.174)\end{array}$ & $\begin{array}{l}0.0674 \\
(0.183)\end{array}$ & $\begin{array}{l}0.0944 \\
(0.168)\end{array}$ & $\begin{array}{l}-0.8755 \\
(0.914)\end{array}$ \\
\hline University patents & $\begin{array}{l}0.0465 \\
(0.107)\end{array}$ & $\begin{array}{l}0.0599 \\
(0.111)\end{array}$ & $\begin{array}{l}0.0479 \\
(0.108)\end{array}$ & $\begin{array}{l}0.0398 \\
(0.108)\end{array}$ & $\begin{array}{l}-0.0961 \\
(0.830)\end{array}$ \\
\hline Univ. industry funds (per employee) & $\begin{array}{l}0.0021^{+} \\
(0.001)\end{array}$ & $\begin{array}{l}0.0018 \\
(0.001)\end{array}$ & $\begin{array}{l}0.0021^{+} \\
(0.001)\end{array}$ & $\begin{array}{l}0.0024^{+} \\
(0.001)\end{array}$ & $\begin{array}{l}-0.0040 \\
(0.018)\end{array}$ \\
\hline Univ. research quality & $\begin{array}{l}-0.3662^{*} \\
(0.163)\end{array}$ & $\begin{array}{l}-0.3840 \\
(0.136)\end{array}$ & $\begin{array}{l}-0.3668^{*} \\
(0.164)\end{array}$ & $\begin{array}{l}-0.3156^{+} \\
(0.164)\end{array}$ & $\begin{array}{l}-0.4412 \\
(1.430)\end{array}$ \\
\hline Region GDP & $\begin{array}{l}0.0000 \\
(0.000)\end{array}$ & $\begin{array}{l}0.0000 \\
(0.000)\end{array}$ & $\begin{array}{l}0.0000 \\
(0.000)\end{array}$ & $\begin{array}{l}0.0000 \\
(0.000)\end{array}$ & $\begin{array}{l}0.0000 \\
(0.000)\end{array}$ \\
\hline Region R\&D & $\begin{array}{l}0.0213 \\
(0.042)\end{array}$ & $\begin{array}{l}0.0139 \\
(0.040)\end{array}$ & $\begin{array}{l}0.0222 \\
(0.041)\end{array}$ & $\begin{array}{l}0.0197 \\
(0.042)\end{array}$ & $\begin{array}{l}0.3817 \\
(0.293)\end{array}$ \\
\hline Region patents & $\begin{array}{l}-0.0002 \\
(0.001)\end{array}$ & $\begin{array}{l}-0.0002 \\
(0.001)\end{array}$ & $\begin{array}{l}-0.0002 \\
(0.001)\end{array}$ & $\begin{array}{l}-0.0002 \\
(0.001)\end{array}$ & $\begin{array}{l}-0.0078 \\
(0.005)\end{array}$ \\
\hline Peers' engagement & $\begin{array}{l}0.1811^{* * *} \\
(0.034)\end{array}$ & $\begin{array}{l}0.1916^{* * *} \\
(0.037)\end{array}$ & $\begin{array}{l}0.1815^{* * *} \\
(0.034)\end{array}$ & $\begin{array}{l}0.1521^{* * *} \\
(0.032)\end{array}$ & $\begin{array}{l}0.4076^{+} \\
(0.205)\end{array}$ \\
\hline Outside peers' engagement & & $\begin{array}{l}0.0389 \\
(0.028)\end{array}$ & & & \\
\hline Peers' academic age & & & $\begin{array}{l}0.0008 \\
(0.002)\end{array}$ & & \\
\hline Peers' perception of benefits & & & & $\begin{array}{l}0.0237^{*} \\
(0.008)\end{array}$ & \\
\hline Constant & $\begin{array}{l}1.7130^{* * *} \\
(0.360)\end{array}$ & $\begin{array}{l}1.8492^{* * *} \\
(0.277)\end{array}$ & $\begin{array}{l}1.7047^{* * *} \\
(0.352)\end{array}$ & $\begin{array}{l}1.4344^{* *} \\
(0.382)\end{array}$ & $\begin{array}{l}1.0480 \\
(3.299)\end{array}$ \\
\hline Observations & 1371 & 1213 & 1371 & 1371 & 52 \\
\hline$R$-squared & 0.239 & 0.236 & 0.239 & 0.244 & 0.638 \\
\hline
\end{tabular}

Notes: Ordinary Least Square, robust standard errors clustered by discipline. Model (5) robust standard errors. University groups included. Two-tailed tests.

$+p<0.10$.

* $p<0.05$.

** $p<0.01$.

*** $p<0.001$.

2014), there may be concerns about its validity. Provided that its components are self-reported by academics, and we use an index method to aggregate them, one may question whether the dependent variable effectively captures what it is supposed to represent, that is the extent of academics' industry engagement. It remains difficult to collect objective information about the entire range of academics engagement efforts. For instance, we lack reliable patent and co-authorship data for all the individuals in our sample. In order to assess the validity of the DV, we computed the correlation between the academic engagement index value and two objective measures of engagement with industry: the amount of EPSRC grants received by an academic that included an industry partner, and the share of an academic's research budget funded by industry as self-reported in the questionnaire. Overall, the correlation of our index value with these two indicators is positive and significant.
The correlation between the index value and EPSRC grants with industry participation is 0.2 and the correlation between the index value and academic' research budget from industry is 0.5 . While the value of the first correlation is relatively low, this may be because EPSRC grants with industry participation are just one way in which academics engage with industry; direct funding from industrial partners is unaccounted for by this method. In turn, since the measure is a composite of many different forms of engagement is unlikely to be directly correlated with any single objective measure of academic engagement. Yet, the degree of correlation between these two variables suggested that AEI has a reasonable overlap with more objective measures. Greater measurement effort will be required in the future to map more accurately academics engagement in different collaboration channels rather than simply relying on self-reported levels of engagement. 
Table 7

Dependent variable splits. This table reports results separately for four broad types of engagement (see Table 1).

\begin{tabular}{|c|c|c|c|c|c|c|c|c|}
\hline \multirow[t]{2}{*}{ Variables } & $(1 \mathrm{~A})$ & $(1 \mathrm{~B})$ & $(2 \mathrm{~A})$ & $(2 \mathrm{~B})$ & $(3 \mathrm{~A})$ & $(3 \mathrm{~B})$ & $(4 \mathrm{~A})$ & $(4 \mathrm{~B})$ \\
\hline & \multicolumn{2}{|c|}{ Joint research } & \multicolumn{2}{|c|}{ Research services } & \multicolumn{2}{|c|}{ Training collaboration } & \multicolumn{2}{|c|}{ Networking } \\
\hline Academic age & $\begin{array}{l}-0.0046^{*} \\
(0.002)\end{array}$ & $\begin{array}{l}-0.0045^{*} \\
(0.002)\end{array}$ & $\begin{array}{l}-0.0053^{+} \\
(0.003)\end{array}$ & $\begin{array}{l}-0.0051^{*} \\
(0.002)\end{array}$ & $\begin{array}{l}-0.0046^{+} \\
(0.002)\end{array}$ & $\begin{array}{l}-0.0046^{+} \\
(0.002)\end{array}$ & $\begin{array}{l}-0.0059^{* *} \\
(0.002)\end{array}$ & $\begin{array}{l}-0.0059^{* *} \\
(0.002)\end{array}$ \\
\hline Industry experience & $\begin{array}{l}0.0136^{* *} \\
(0.004)\end{array}$ & $\begin{array}{l}0.0135^{* *} \\
(0.004)\end{array}$ & $\begin{array}{l}0.0284^{* * *} \\
(0.003)\end{array}$ & $\begin{array}{l}0.0287^{* * * *} \\
(0.003)\end{array}$ & $\begin{array}{l}0.0115^{*} \\
(0.004)\end{array}$ & $\begin{array}{l}0.0116^{*} \\
(0.004)\end{array}$ & $\begin{array}{l}0.0121^{*} \\
(0.004)\end{array}$ & $\begin{array}{l}0.0121^{*} \\
(0.004)\end{array}$ \\
\hline Star scientist & $\begin{array}{l}-0.0519 \\
(0.080)\end{array}$ & $\begin{array}{l}-0.0508 \\
(0.077)\end{array}$ & $\begin{array}{l}-0.0437 \\
(0.071)\end{array}$ & $\begin{array}{l}-0.0336 \\
(0.075)\end{array}$ & $\begin{array}{l}-0.0900 \\
(0.112)\end{array}$ & $\begin{array}{l}-0.0860 \\
(0.114)\end{array}$ & $\begin{array}{l}-0.0241 \\
(0.071)\end{array}$ & $\begin{array}{l}-0.0271 \\
(0.076)\end{array}$ \\
\hline Peers' behaviour & $\begin{array}{l}0.1006^{* *} \\
(0.029)\end{array}$ & $\begin{array}{l}0.1777^{* * *} \\
(0.035)\end{array}$ & $\begin{array}{l}0.1489^{* * * *} \\
(0.021)\end{array}$ & $\begin{array}{l}0.2728^{* * * *} \\
(0.041)\end{array}$ & $\begin{array}{l}0.1434^{* * * *} \\
(0.030)\end{array}$ & $\begin{array}{l}0.2585^{* * *} \\
(0.053)\end{array}$ & $\begin{array}{l}0.1507^{* *} \\
(0.037)\end{array}$ & $\begin{array}{l}0.1457^{+} \\
(0.080)\end{array}$ \\
\hline Peers' behaviour $\times$ academic age & & $\begin{array}{l}-0.0034^{*} \\
(0.001)\end{array}$ & & $\begin{array}{l}-0.0051^{* *} \\
(0.001)\end{array}$ & & $\begin{array}{l}-0.0054^{*} \\
(0.002)\end{array}$ & & $\begin{array}{l}0.0002 \\
(0.004)\end{array}$ \\
\hline Peers' behaviour $\times$ star scientist & & $\begin{array}{l}0.0231 \\
(0.072)\end{array}$ & & $\begin{array}{l}-0.0671 \\
(0.061)\end{array}$ & & $\begin{array}{l}-0.0411 \\
(0.068)\end{array}$ & & $\begin{array}{l}0.0120 \\
(0.064)\end{array}$ \\
\hline \multicolumn{9}{|l|}{ Outside peers' behaviour } \\
\hline Constant & $\begin{array}{l}1.2237^{*} \\
(0.483)\end{array}$ & $\begin{array}{l}1.2552^{*} \\
(0.482)\end{array}$ & $\begin{array}{l}0.8711 \\
(0.571)\end{array}$ & $\begin{array}{l}0.8673 \\
(0.565)\end{array}$ & $\begin{array}{l}0.7502 \\
(0.504)\end{array}$ & $\begin{array}{l}0.7582 \\
(0.490)\end{array}$ & $\begin{array}{l}1.4565^{* * *} \\
(0.250)\end{array}$ & $\begin{array}{l}1.4534^{* * *} \\
(0.252)\end{array}$ \\
\hline Observations & 1371 & 1371 & 1371 & 1371 & 1371 & 1371 & 1371 & 1371 \\
\hline$R$-squared & 0.133 & 0.135 & 0.208 & 0.213 & 0.136 & 0.141 & 0.127 & 0.127 \\
\hline
\end{tabular}

Notes: Ordinary Least Squares, robust standard errors clustered by discipline. Control variables included.

For each regression, Peers' behaviour includes the same items included in the dependent variable.

Two-tailed tests.

$+p<0.10$.

* $p<0.05$.

** $p<0.01$.

*** $p<0.001$.

As a final robustness check, we explore the characteristics of the researchers who were dropped from the analysis because of lack of information on their peer groups. By construction, we expect that researchers from smaller universities and smaller departments will be more likely to be excluded from the analysis since the likelihood of multiple observations from those institutions is smaller than in the case of researchers affiliated to larger universities and departments. We found evidence that researchers from large universities and large departments were oversampled in the final regression compared to the distribution in the original sample of academics who responded to the questions about industry engagement activities (1895). We estimated a logistic regression to obtain the probability of being included in the regression as a function of the size of the department and university of affiliation. We used the inverse of this probability as a weight in the estimation of our main model; the results were unchanged.

\section{Discussion}

Our analysis suggests that academics' engagement with industry is informed by the behaviour of their departmental peers. Observing colleagues' behaviours appears to exert pressure on individuals to emulate such behaviour. We postulated that the cause of this finding is the mechanism of social comparison which allows individuals to derive self-worth by comparing themselves with similar others and competing with them for professional status and achievement. This reasoning is strengthened by the finding that peer influence is weaker for individuals who are more senior and for higher-performing individuals. Junior scientists are more likely to be influenced by local peers when deciding whether to engage with industry because for this group, local peers are a more salient reference group in relation to self-evaluation and academic achievement in a competitive context. In turn, compared to lower performers, star performers are less influenced by local peers as they may look further a field for reference points when competing professionally. However, we found only modest support for this latter finding; the coefficient shows modest statistical significance.
Our study makes several contributions. First, we add to the work on university-industry relations and commercialization of university technologies. Researchers have long been interested in what drives academic scientists to work with industry, thereby facilitating the transfer of knowledge and technology from universities to industry (Louis et al., 1989; Mansfield, 1995; Owen-Smith and Powell, 2001; Murray, 2002; Siegel et al., 2003; Haeussler and Colyvas, 2011). There is a strand in the literature that highlights individual behaviour as being strongly informed by the social context of the university or department (Stuart and Ding, 2006; Bercovitz and Feldman, 2008). Our study contributes to this line of work by pointing to a mechanism that promotes this local context influence. When deciding to engage proactively with industry-which effectively is discretionary behaviour-academic scientists mimic the average behaviour of departmental work colleagues at a similar stage in their careers. We suggest that this effect is produced by social comparison, meaning that scientists compare themselves with relevant others who are their departmental peers. Social comparison suggests an element of rivalry and competition motivating scientists' industry engagement strategies. In other words, academic scientists may decide to engage with industry in order to match the performance levels of their colleagues, and to improve their career prospects. While previous research has explored various facets of competition in academia, such as the race for priority in publishing (Hagstrom, 1974) and the struggle for resources (Merton, 1968), our findings suggest that competition may also be a motivation for academic scientists' proactive efforts to collaborate with industrial users of their research. The link between industry engagement and academic career progress suggests that industry engagement may be more closely aligned with an academic's professional progress in the world of science than is suggested by studies that view collaboration with industry as a distinct from the universities' other missions (Etzkowitz, 2003).

Our study also provides a broader view of academic engagement with industry than academic entrepreneurship, which is often regarded as the most visible and impactful mode of scientists' interaction with the private sector. Much of the research on university-industry relations highlights the incidence and 
impact of academic scientists' entrepreneurial activities in the form of patent applications and the founding of academic spinoffs (Agrawal and Henderson, 2002; Shane, 2002). While patents and licensing are certainly important means of technology transfer, they account for only part of the information transferred from universities (Agrawal and Henderson, 2002). Our academic engagement index allowed us to capture more frequent collaboration behaviours than the types explored in other studies. In many disciplines, large numbers of academic faculty routinely participate in collaborative engagement with industry via joint research, consulting, or contract research (Louis et al., 1989; Gulbrandsen and Smeby, 2005; D'Este and Patel, 2007). Characterizing these as engagement behaviours allows us to account for the fact that academics may exploit them for reasons other than entrepreneurship. These reasons can include mobilizing resources for their academic research projects, and sources for new ideas that may shape their future research agendas (Rosenberg, 1982; Mansfield, 1995). The novel insight that we bring to this body of scholarship is that engagement with industry may be fuelled by an individual's desire to compete effectively in the academic profession. By implication, our results tentatively suggest that at the department level, industry engagement appears to be a function of the group dynamics and individuals' responses to it, rather than a response to a departmental top-down imposition of rules and norms as suggested by prior studies. However, the incidence of peer effects in our study does not categorically exclude the presence of other effects. Indeed, it is not possible for us to rule out effects related to social learning among peers in addition to social comparison.

Our study also contributes to the literature by attempting to overcome the problems related to testing claims about the influence of peers. First, we use a large, comprehensive dataset characterizing the activities of individuals and their peers. This includes academic researchers active in a wide range of disciplines and universities and goes beyond the focus in the literature on the role of social context related to life-sciences. Second, we explore the determinants of a range of industry collaboration including consulting, contract research, joint research and training of company employees. This allows us to develop insights that are applicable to widely practised activities rather than relatively rare activities, such as entrepreneurship. Third, in testing peer effects, we address the problem that the correlation between peers' behaviour and individual engagement with industry may be spurious and afflicted by identification problems - a problem common to all studies of group effects on individual behaviour (Manski, 1993). On the one hand, we seek to exclude the possibility of the presence of contextual interactions by showing that individual behaviours do not vary with exogenous characteristics of the group members. On the other hand, we separate the impact of social effects from the influence of common unobservable characteristics by including rich information on the environment in which these academics operate. We also distinguish between different groups of colleagues, following the idea proposal in Munshi and Myaux (2006) and Sorensen (2006), according to which estimated peer effects should be stronger when the social group is defined more narrowly. Finally, we attempt to address the reflection problem. Previous work predominantly focuses on manifested behaviours in attempting to establish the impact of local social contexts (Louis et al., 1989; Sorensen, 2006; Stuart and Ding, 2006; Bercovitz and Feldman, 2008; Nanda and Sorensen, 2010). Our approach moves in the direction of Manski's (2000) suggestion and adds to these works by considering the separate impacts of peers' perceptions and behaviours on individual actions.

Finally, our results also have implications for the study of professional services organizations because, in many respects, academic departments have features in common with practice areas in these organizations. Universities, like other professional services firms, are professional bureaucracies (Mintzberg, 1983) where highly skilled individuals work relatively autonomously with groups and 'clients' external to their organizations. For all these organizations, employees' discretionary behaviours are crucial for acquiring external resources and 'getting the job done'. Our study suggests that individual behaviour is shaped to a great extent by peers in the immediate work environment. Comparing oneself with peers appears to have a major influence on the individual's decision to engage in behaviour that is not unequivocally prescribed by organizational policies. In this context, note that 'outside peers', i.e. local colleagues who are either more junior or more senior than the focal individual, do not appear to inform individual's behaviour. This suggests that individuals are strongly oriented towards what they perceive to be their generalized other, suggesting that immediate peer groups represent opportunities for generating professional identities which in turn inform individuals' attitudes and behaviours (Ibarra, 1999).

\section{Implications, limitations and future research}

Understanding the social mechanisms that lead academics to engage with industry contributes to the wider issue related to how universities and organizations in general, should be managed, and specifically with respect to the promotion of proactive behaviour by organization members. Our findings suggest that direct incentives offered by senior members, such as heads of university departments, to encourage employees to behave proactively in relation to seeking engagement with industrial partners may be only partially effective. Similar to what happens when we observe the tension between bureaucracy and entrepreneurship (Ruef and Lounsbury, 2007), proactive behaviours are hard to incentivize or dictate. Because organizational members are influenced by colleagues of the same rank, attempts to promote (or discourage) engagement should include collective influence on organizational members which will stimulate emulation by peers and result in a virtual cycle of mutual reinforcement. A cultural approach to framing industry engagement positively, and emphasizing its complementarities with academic work more generally, would appear appropriate to nurture the former aspect, while greater transparency would enable individuals to view their colleagues' behaviour and promote emulation. Hiring policies need to take account of the fact that employing faculty with experience of working with industry may increase the likelihood that departmental colleagues of the same rank will mimic this behaviour.

This study has some limitations, which suggest directions for future research. First, we rely on survey data to construct the activities not only of the focal individuals but also of the members of their department of affiliation. While we possess information on a large number of researchers, we cannot ensure complete representativeness of departments. Future research should rely on universities' archival data in order to construct precise measures of departments' engagement activities with industry. Similar to other work on peer effects, despite all the measures taken, our study may still suffer from sorting bias. Future research could exploit career history data in order to assess whether academics are sorted into departments because of their preference for engagement activities, and could exploit panel data to analyse the dynamics of departmental peers' behaviour when a new faculty member joins the group.

\section{Acknowledgments}

Ammon Salter and Valentina Tartari gratefully acknowledge the support of the UK's Engineering and Physical Sciences Research Council [EP/F036930/1], Economic and Social Research Council (ESRC) [ES/K001159/1] and the Innovation Research Centre 
[RES/G028591/1], which was sponsored by the ESRC; the National Endowment for Science, Technology and the Arts; the Department for Business, Innovation and Skills; and the Technology Strategy Board. Markus Perkmann also acknowledges support from the ESRC (RES-331-27-0063). The authors are grateful for helpful comments and discussion from the editor, two anonymous referees, Oliver Alexy, Tom Astebro, Maryann Feldman, Alfonso Gambardella, Keld Laursen, Aija Leiponen, Toke Reichstein and participants of seminars at the Academy of Management, DRUID, Carlos III, Copenhagen Business School, University of Groningen, Imperial College London, Tilburg University, and Utrecht University.

\section{Appendix.}

Researchers' motivations for engaging with industry.

\begin{tabular}{|c|c|}
\hline Motivation & $\%$ of respondents ${ }^{\mathrm{a}}$ \\
\hline Source of additional research income & 69.7 \\
\hline $\begin{array}{l}\text { Increasing the likelihood of application of my } \\
\text { research outside academia }\end{array}$ & 66.6 \\
\hline $\begin{array}{l}\text { Raising awareness of problems that industry } \\
\text { confronts }\end{array}$ & 59.3 \\
\hline $\begin{array}{l}\text { Building and sustaining your professional } \\
\text { network }\end{array}$ & 53.0 \\
\hline $\begin{array}{l}\text { Keeping abreast of research conducted in } \\
\text { industry }\end{array}$ & 51.9 \\
\hline Getting inspiration for new research projects & 50.8 \\
\hline $\begin{array}{l}\text { Feedback from industry about viability of } \\
\text { research }\end{array}$ & 46.1 \\
\hline $\begin{array}{l}\text { Access to materials or data necessary for } \\
\text { research }\end{array}$ & 40.1 \\
\hline Training of postgraduate students & 34.5 \\
\hline $\begin{array}{l}\text { Helping students to find employment in } \\
\text { industry }\end{array}$ & 33.6 \\
\hline $\begin{array}{l}\text { Access to research expertise of industry } \\
\text { employees }\end{array}$ & 30.0 \\
\hline $\begin{array}{l}\text { Improving the understanding of foundations of } \\
\text { particular phenomena }\end{array}$ & 24.4 \\
\hline $\begin{array}{l}\text { Access to state-of-the art equipment, facilities } \\
\text { and instruments }\end{array}$ & 18.4 \\
\hline Seeking proprietary knowledge (e.g. patents) & 12.3 \\
\hline Source of personal income & 10.8 \\
\hline
\end{tabular}

a Percentage of respondents indicating 'very important' or 'crucial' when responding to the question: how frequently have you been engaged in the following types of activity with industry in the last two years (calendar years 2007 and 2008)?

\section{References}

Adams, J.D., Black, G.C., Clemmons, J.R., Stephan, P.E., 2005. Scientific teams and institutional collaborations: evidence from U.S. universities, 1981-1999. Res. Policy 34, 259-285.

Agrawal, A., Henderson, R.M., 2002. Putting patents in context: exploring knowledge transfer from MIT. Manage. Sci. 48, 44-60.

Alpert, D., 1985. Performance and paralysis: the organizational context of the American research university. J. Higher Educ. 56, 241-281.

Aschhoff, B., Grimpe, C., 2014. Contemporaneous peer effects, career age and the industry involvement of academics in biotechnology. Res. Policy 43, 367-381.

Audretsch, B., 1998. Agglomeration and the location of innovative activity. Oxf. Rev. Econ. Pol. 14, 18-29.

Azoulay, P., Ding, W., Stuart, T., 2007. The determinants of faculty patenting behavior: demographics or opportunities? J. Econ. Behav. Organ. 63, 599-623.

Azoulay, P., Zivin, J.S.G., Wang, J., 2008. Superstar Extinction. National Bureau of Economic Research Working Paper Series No. 14577.

Baldwin, R.G., Blackburn, R.T., 1981. The academic career as a developmental process: implications for higher education. J. Higher Educ. 52, 598-614.

Bekkers, R., Bodas Freitas, I.M., 2008. Analysing knowledge transfer channels between universities and industry: to what degree do sectors also matter? Res. Policy 37, 1837-1853.

Bercovitz, J., Feldman, M., 2007. Academic entrepreneurs and technology transfer: who participates and why. In: Malerba, F., Brusoni, S. (Eds.), Perspectives on Innovation. Cambridge University Press, Cambridge, pp. 381-398.

Bercovitz, J., Feldman, M., 2008. Academic entrepreneurs: organizational change at the individual level. Organ. Sci. 19, 69-89.

Blumenthal, D., Campbell, C., Causino, N., Louis, K.S., 1996. Participation of lifescience faculty in research relationships with industry. N. Engl. J. Med. 335, 1734.

Boardman, P.C., Ponomariov, B.L., 2009. University researchers working with private companies. Technovation 29, 142-153.
Bozeman, B., Gaughan, M., 2007. Impacts of grants and contracts on academic researchers' interactions with industry. Res. Policy 36, 694-707.

Breschi, S., Lissoni, F., Montobbio, F., 2007. The scientific productivity of academic inventors: new evidence from Italian data. Econ. Innovat. New Technol. 16, 101.

Clarysse, B., Tartari, V., Salter, A., 2011. The Comparative Role of TTOs and Individua Level behaviour of Academics to Explain Academic Entrepreneurship. Research Policy 40 (8), 1084-1093.

Cohen, W.M., Nelson, R.R., Walsh, J.P., 2002. Links and impacts: the influence of public research on industrial R\&D. Manage. Sci. 48, 1-23.

Cole, J.R., Cole, S., 1974. Social stratification in science. Am. J. Phys. 42, 923.

Coleman, J.S., 1966. Equality of Educational Opportunity. US Government Printing Office, Washington, DC.

D’Este, P., Patel, P., 2007. University-industry linkages in the UK: what are the factors underlying the variety of interactions with industry? Res. Policy 36, 1295 1313.

D'Este, P., Perkmann, M., 2011. Why do academics engage with industry? The entrepreneurial university and individual motivations. J. Technol. Transf. 36 316-339.

Di Gregorio, D., Shane, S., 2003. Why do some universities generate more start-ups than others? Res. Policy 32, 209-227.

Dietz, R.D., 2002. The estimation of neighborhood effects in the social sciences: an interdisciplinary approach. Soc. Sci. Res. 31, 539-575.

Etzkowitz, H., 2003. Research groups as 'quasi-firms': the invention of the entrepreneurial university. Res. Policy 32, 109-121.

EUROSTAT, 2003. REGIO. European Commission.

Fabrizio, K.R., Di Minin, A., 2008. Commercializing the laboratory: faculty patenting and the open science environment. Res. Policy 37, 914-931.

Feller, I., 1990. Universities as engines of R\&D-based economic growth: they think they can. Res. Policy 19, 335-348.

Festinger, L., 1954. A theory of social comparison processes. Hum. Relat. 7, 117-140.

Freeman, R., Weinstein, E., Marincola, E., Rosenbaum, J., Solomon, F., 2001. Competition and careers in biosciences. Science 294, 2293-2294.

Furman, J.L., Jensen, K., Murray, F., 2012. Governing knowledge in the scientific community: exploring the role of retractions in biomedicine. Res. Policy 41 , 276-290.

Geuna, A., Muscio, A., 2009. The governance of university knowledge transfer: a critical review of the literature. Minerva 47, 93-114.

Geuna, A., Nesta, L.J.J., 2006. University patenting and its effects on academic research: the emerging European evidence. Res. Policy 35 (6), 790-807.

Giuliani, E., Morrison, A., Pietrobelli, C., Rabellotti, R., 2010. Who are the researchers that are collaborating with industry? An analysis of the wine sectors in Chile South Africa and Italy. Res. Policy 39, 748-761.

Gulbrandsen, M., Smeby, J.C., 2005. Industry funding and university professors research performance. Res. Policy 34, 932-950.

Guryan, J., Kroft, K., Notowidigdo, M., 2007. Peer Effects in the Workplace: Evidence from Random Groupings in Professional Golf Tournaments. National Bureau of Economic Research.

Haeussler, C., Colyvas, J.A., 2011. Breaking the Ivory Tower: academic entrepreneurship in the life sciences in UK and Germany. Res. Policy 40, 41-54.

Hagstrom, W.O., 1974. Competition in science. Am. Sociol. Rev. 39, 1-18.

HEFCE, 2008a. Higher Education-Business and Community Interaction Survey 2006-2007, July 2008 ed. Higher Education Council Funding for England.

HEFCE, 2008b. Research Assessment Exercise, 30 April 2009 ed.

Hogg, M.A., Abrams, D., 1988. Social Identifications: A Social Psychology of Intergroup Relations and Group Processes. Routledge, London and New York.

Hyman, H.H., 1942. The psychology of status. Arch. Psychol. (Columbia University) 269, 94.

Ibarra, H., 1999. Provisional selves: experimenting with image and identity in professional adaptation. Adm. Sci. Q. 44, 764-791.

Ibarra, H., Andrews, S.B., 1993. Power, social influence, and sense making: effects of network centrality and proximity on employee perceptions. Adm. Sci. Q. 38 277-303.

Jackson, C.K., Bruegmann, E., 2009. Teaching students and teaching each other: the importance of peer learning for teachers. Am. Econ. J.: Appl. Econ. 1, 85-108.

Jones, B.F., Wuchty, S., Uzzi, B., 2008. Multi-university research teams: shifting impact, geography, and stratification in science. Science 322, 1259-1262.

Kassicieh, S.K., Radosevich, R., Umbarger, J., 1996. A comparative study of entrepreneurship incidence among inventors in national laboratories. Entrep. Theory Pract. 20, 33-50.

Kemper, T.D., 1968. Reference groups, socialization and achievement. Am. Sociol Rev. 33, 31-45.

Kenney, M., Goe, R.W., 2004. The role of social embeddedness in professoria entrepreneurship: a comparison of electrical engineering and computer science at UC Berkeley and Stanford. Res. Policy 33, 691-707.

Knorr-Cetina, K.D., Harré, R., 1981. The Manufacture of Knowledge: An Essay on the Constructivist and Contextual Nature of Science. Pergamon Press, Oxford.

Krabel, S., Mueller, P., 2009. What drives scientists to start their own company? An empirical investigation of Max Planck Society scientists. Res. Policy 38, 947-956.

Landry, R., Amara, N., Rherrad, I., 2006. Why are some university researchers more likely to create spin-offs than others? Evidence from Canadian universities. Res. Policy 35, 1599-1615.

Lazega, E., 2000. Rule enforcement among peers: a lateral control regime. Organ. Stud. 21, 193-214.

Link, A.N., Siegel, D.S., Bozeman, B., 2007. An empirical analysis of the propensity of academics to engage in informal university technology transfer. Ind. Corp. Change 16, 641-655. 
Lockett, A., Wright, M., 2005. Resources, capabilities, risk capital and the creation of university spin-out companies. Res. Policy 34, 1043-1057.

Louis, K.S., Blumenthal, D., Gluck, M.E., Stoto, M.A., 1989. Entrepreneurs in academe: an exploration of behaviors among life scientists. Adm. Sci. Q. 34, 110-131.

Mansfield, E., 1991. Academic research and industrial innovation. Res. Policy 20, $1-12$.

Mansfield, E., 1995. Academic research underlying industrial innovations: sources, characteristics, and financing. Rev. Econ. Stat. 77, 55-65.

Manski, C.F., 1993. Identification of endogenous social effects: the reflection problem. Rev. Econ. Stud. 60, 531.

Manski, C.F., 2000. Economic analysis of social interactions. J. Econ. Perspect. 14, 115-136.

Mas, A., Moretti, E., 2009. Peers at Work. Am. Econ. Rev. 99 (1), 112-145.

Merton, R., Kitt, A.S., 1950. Contributions to the theory of reference group behavior. In: Merton, R., Lazarsfeld, P.F. (Eds.), Continuities in Social Research: Studies in the Scope and Method of the American Soldier. The Free Press, Glencoe, IL.

Merton, R.K., 1968. The Matthew effect in science. The reward and communication systems of science are considered. Science 159, 56-63.

Merton, R.K., 1973. The Sociology of Science. Theoretical and Empirical Investigations. University of Chicago Press, Chicago.

Mintzberg, H., 1983. Structure in Fives: Designing Effective Organizations, International ed. Prentice Hall, Upper Saddle River.

Moretti, E., 2011. Social learning and peer effects in consumption: evidence from movie sales. Rev. Econ. Stud. 78, 356-393.

Mowery, D.C., 2009. Plus ca change: industrial R\&D in the "third industrial revolution". Ind. Corp. Change 18, 1-50.

Mowery, D.C., Nelson, R.R., Sampat, B.N., Ziedonis, A.A., 2001. The growth of patenting and licensing by US universities: an assessment of the effects of the Bayh-Dole Act of 1980. Res. Policy 30, 99-119.

Munshi, K., Myaux, J., 2006. Social norms and the fertility transition. J. Dev. Econ. 80 $1-38$

Murray, F., 2002. Innovation as co-evolution of scientific and technologica networks: exploring tissue engineering. Res. Policy 31, 1389-1403.

Mussweiler, T., Strack, F., 2000. The "relative self": informational and judgmenta consequences of comparative self-evaluation. J. Pers. Soc. Psychol, 79, 23-38.

Nanda, R., Sorensen, J.B., 2010. Workplace peers and entrepreneurship. Manage. Sci $56,1116-1126$

Nelson, R.R., Rosenberg, N., 1994. American universities and technical advance. Res. Policy 23, 323-348.

Owen-Smith, J., Powell, W.W., 2001. To patent or not: faculty decisions and institutional success at technology transfer. J. Technol. Transf. 26, 99-114.

Perkmann, M., Tartari, V., McKelvey, M., Autio, E., Broström, A., D’Este, P., Fini, R. Geuna, A., Grimaldi, R., Hughes, A., Krabel, S., Kitson, M., Llerena, P., Lissoni, F., Salter, A., Sobrero, M., 2013. Academic engagement and commercialisation: a review of the literature on university-industry relations. Res. Policy 42 423-442.

Ponomariov, B., 2008. Effects of university characteristics on scientists' interactions with the private sector: an exploratory assessment. J. Technol. Transf. 33, 485-503.
Renault, C., 2006. Academic capitalism and university incentives for faculty entrepreneurship. J. Technol. Transf. 31, 227-239.

Rosenberg, N., 1982. Inside the Black Box: Technology and Economics. Cambridge University Press, Cambridge.

Ruef, M., Lounsbury, M., 2007. Introduction: the sociology of entrepreneurship. In: Ruef, M., Lounsbury, M. (Eds.), Research in the Sociology of Organizations. Emerald Group Publishing Limited, pp. 1-29.

Shane, S., 2002. Selling university technology: patterns from MIT. Manage. Sci. 48 $122-137$.

Shibutani, T., 1955. Reference groups as perspectives. Am. J. Sociol. 60, 562-569.

Siegel, D.S., Waldman, D.A. Atwater, L.E Link, A. N. 2003. Commercial knowledge transfers from universities to firms: improving the effectiveness of university-industry collaboration. J. High Technol. Manage. Res. 14, 111133.

Sorensen, A.T., 2006. Social learning and health plan choice. Rand J. Econ. 37 929-945.

Stephan, P.E., 1996. The economics of science. J. Econ. Lit. 34, 1199-1235.

Stephan, P.E., Everhart, S.S., 1998. The changing rewards to science: the case of biotechnology. Small Bus. Econ. 10, 141-151.

Stokes, D.E., 1997. Pasteur's Quadrant: Basic Science and Technological Innovation. Brookings Institution Press, Washington, DC

Stuart, T.E., Ding, W.W., 2006. When do scientists become entrepreneurs? The socia structural antecedents of commercial activity in the academic life sciences. Am. J. Sociol. 112, 97-144.

Tafjel, H., 1981. Human Groups and Social Categories: Studies in Social Psychology. CUP Archive, Cambridge.

Tartari, V., Salter, A., D’Este, P., 2012. Crossing the rubicon: exploring the factors that shape academics perceptions of the barriers of working with industry. Cambridge Journal of Economics 36 (3), 655-677.

Tartari, V., Salter, A., 2013. The engagement gap: gender differences in universityindustry collaboration activities. Academy of Management Proceedings.

Turner, J.C., Hogg, M.A., Oakes, P.J., Reicher, S.D., Wetherell, M.S., 1987. Rediscovering the Social Group: A Self-Categorization Theory. Basil Blackwell, Cambridge, MA

Whitley, R., 2000. The Intellectual and Social Organisation of the Sciences. Oxford University Press, Oxford.

Wills, T.A., 1981. Downward comparison principles in social psychology. Psychol Bull. 90, 245.

Wright, M., Birley, S., Mosey, S., 2004. Entrepreneurship and university technology transfer. J. Technol. Transf. 29, 235-246.

Zimmerman, D.J., 2003. Peer effects in academic outcomes: evidence from a natura experiment. Rev. Econ. Stat. 85, 9-23.

Zucker, L.G., Darby, M.R., 1996. Star scientists and institutional transformation: patterns of invention and innovation in the formation of the biotechnology industry. PNAS 93, 12709-12716

Zucker, L.G., Darby, M.R., 2001. Capturing technological opportunity via Japan's star scientists: evidence from Japanese firms' biotech patents and products. J. Technol. Transf. 26, 37-58.

Zuckerman, H., 1970. Stratification in American Science. Sociol. Inq. 40, 235-257. 